\title{
MONETARY POLICY RULE, EXCHANGE RATE REGIME, AND FISCAL POLICY CYCLICALITY IN A DEVELOPING OIL ECONOMY
}

\author{
Aliya Algozhina
}
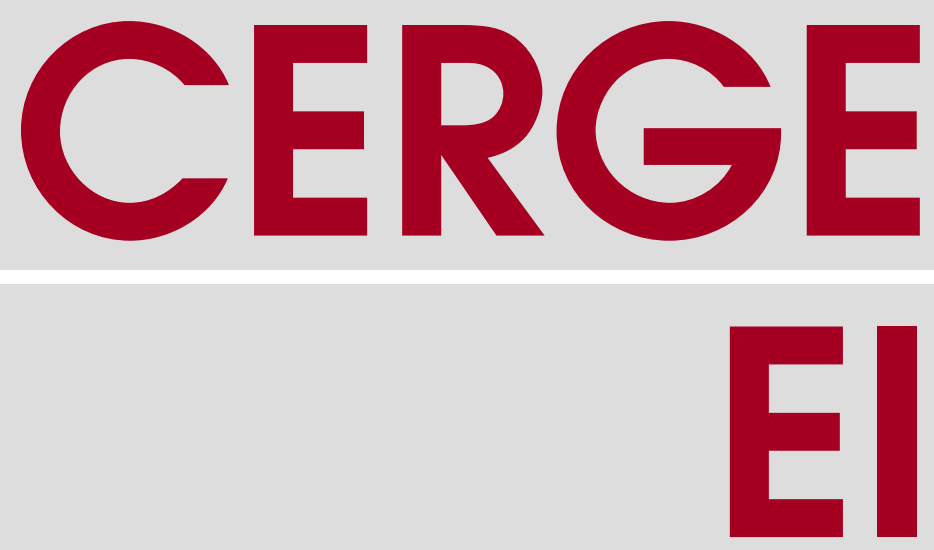


\section{Working Paper Series 572 (ISSN 1211-3298)}

\section{Monetary Policy Rule, Exchange Rate Regime, and Fiscal Policy Cyclicality in a Developing Oil Economy}

Aliya Algozhina

CERGE-EI

Prague, October 2016 
ISBN 978-80-7343-379-6 (Univerzita Karlova, Centrum pro ekonomický výzkum a doktorské studium)

ISBN 978-80-7344-395-5 (Národohospodářský ústav AV ČR, v. v. i.) 


\title{
Monetary Policy Rule, Exchange Rate Regime, and Fiscal Policy Cyclicality in a Developing Oil Economy
}

\author{
Aliya Algozhina* \\ CERGE-EI ${ }^{\dagger}$
}

October 2016

\begin{abstract}
According to Frankel and Catao (2011), a commodity exporting developing economy is advised to target the output price index rather than consumer price index, as the former monetary policy is automatically countercyclical against the volatile terms of trade shock. This paper constructs a dynamic stochastic general equilibrium model of joint monetary and fiscal policies for a developing oil economy, to find an appropriate monetary rule combined with a pro/counter/acyclical fiscal stance based on a loss measure. The foreign exchange interventions distinguish between a managed and flexible exchange rate regime, while fiscal policy cyclicality depends on the oil output response of public consumption and public investment. The study reveals that the best policy combination is a countercyclical fiscal stance and CPI inflation monetary targeting under a flexible exchange rate regime to stabilize equally the domestic price inflation, aggregate output, and real exchange rate in a small open economy. This result is conditional on weights for those three variables used in the loss measure.

Keywords: oil economy, monetary policy, fiscal policy, exchange rate, oil price shock, interventions, SWF

JEL Classification: E31, E52, E62, E63, F31, F41, H54, H63, Q33, Q38

${ }^{*}$ The author thanks Sergey Slobodyan and anonymous referees of the Czech Journal of Economics and Finance for their constructive comments. Special thanks go to Andrea Downing for her edit. All errors remaining in this text are the responsibility of the author (e-mail: Aliya.Algozhina@cerge-ei.cz). The financial support of the Czech Science Foundation project No. P402/12/G097 "DYME - Dynamic Models in Economics" is acknowledged. The work is also supported by the GACR grant P402-11J018 "Comparative Approach to Macroeconomic Modeling and Policy Analysis: Introducing Adaptive Learning".

${ }^{\dagger}$ CERGE-EI (Center for Economic Research and Graduate Education - Economics Institute) is a joint workplace of Charles University and the Economics Institute of the Czech Academy of Sciences, Politických vězñu 7, Prague, 11121, Czech Republic.
\end{abstract}




\section{Introduction}

Most macroeconomic DSGE models are constructed for the developed world, incorporating its advanced market structure and relevant policy environment. Emerging market economies have their own unique features, which can modify the existing core frameworks in several respects. First, public investment should be considered separately from public consumption as a growth inducing instrument of fiscal policy (Berg, Portillo, Yang \& Zanna, 2013), since it is usually associated with infrastructure and human capital, which developing countries often lack (Rioja, 2003; Sab \& Smith, 2002). Second, monetary policy is typically a hybrid of inflation targeting and a managed exchange rate regime; thus, interest rate and foreign exchange interventions represent the two separate instruments of monetary policy (Ostry et al., 2012). Third, in an underdeveloped domestic financial market, the investments of firms are often financed by foreign funds, so that physical capital and foreign debt can be linked through a collateral constraint (Faia \& Iliopulos, 2011). Fourth, households are heterogeneous in their income and access to a financial market; a certain portion of the population may be liquidity constrained having only wages, without making savings (Mankiw, 2000; Gali, Lopez-Salido \& Valles, 2007). These four structural specifics are incorporated in the model of Algozhina (2012) calibrated for Hungary as the first emerging market economy to be severely hit by the global financial crisis of 2008 .

This paper extends Algozhina (2012) for a subset of emerging open economies which export oil. The oil exporting developing economies obviously differ from other emerging countries and need to be examined through their own DSGE framework. The particular features of an oil economy are as follows: The oil and non-oil production sectors should be specified separately. The economy is exposed to a volatile exogenous world oil price shock. A Sovereign Wealth Fund (SWF) is established collecting the oil tax revenues, saving them abroad, and partly transferring to the government budget $^{1}$, and the foreign exchange interventions are related to central bank's reserves that may affect the interest rate according to a mechanism described by Benes et al. (2015). Finally, motivated by

\footnotetext{
${ }^{1}$ The mechanism of SWF accumulation differs across countries, but since the model is calibrated for Kazakhstan, its experience is specifically captured.
} 
Frankel and Catao (2011), monetary policy can follow product price targeting (PPT) as an alternative to consumer price index (CPI); thus, these two anchors need to be compared in a general equilibrium framework jointly with fiscal policy based on some welfare measure, to find out which one is preferred.

Frankel and Catao (2011) argue that commodity exporting economies are better off targeting the output price index, which includes export commodities and excludes import products; such monetary policy is automatically countercyclical against the volatile terms of trade shock. The argument is, that if the world oil price increases and there is PPT, then monetary policy tightens by raising its interest rate, thus causing exchange rate appreciation, which is the objective of offsetting the initial positive terms of trade shock. Conversely, an adverse terms of trade shock, such as a fall in oil price, can be mitigated by the exchange rate depreciation under PPT. The CPI inflation targeting, in contrast, does not respond to export prices, but to import prices. If there is an adverse terms of trade shock, such as an increase of import prices, CPI targeting brings exchange rate appreciation, further exacerbating the initial negative shock for producers of tradable goods, who use imports as their intermediate inputs. "Bottom line: a Product Price Targeter would appreciate in response to an increase in world prices of its commodity exports, not in response to an increase in world prices of its imports. CPI targeting gets this backwards." (Frankel \& Catao, 2011, p. 4).

The aim of this paper is to construct a DSGE model for a developing, resource-rich economy capturing its structural specifics, as defined above, to examine the CPI/PPT monetary policy rule under a flexible/managed exchange rate regime combined with a pro/counter/acyclical fiscal policy. The calibration is based on Kazakhstan as a small open, oil exporting economy severely hit by the global financial crisis of 2008 due to high private sector's foreign debt.

Since 2006, the IMF has included Kazakhstan in its "fuel exporters" group analyzed in the World Economic Outlook ${ }^{2}$. In 2000, Kazakhstan established its SWF managed by the

\footnotetext{
${ }^{2}$ The classification is made on the evidence that over five years the average share of fuel exports in total exports exceeds 40 percent.
} 
National Bank on behalf of the Ministry of Finance. Oil tax revenues directly accumulate the SWF which is invested abroad, but regularly, there are ad hoc transfers from SWF to the government budget. Monetary policy is independently conducted by the National Bank pursuing a primary goal of price stability and intervening in the foreign exchange market to avoid speculative attacks.

In order to assess whether an anchor of price stability should be the CPI or PPT, a welfare measure is adopted. According to De Paoli (2009), the welfare for a small open economy is represented as a loss function of three variables: variations in domestic price inflation, aggregate output, and real exchange rate. Based on this loss measure, two Taylor rule's parameters are optimized for managed and flexible exchange rate regimes, distinguished by the presence of foreign exchange interventions.

Fiscal policy cyclicality is associated with the oil output response of public spending. This is because the business cycle of an oil producing economy tends to correlate more with its oil sector's output rather than aggregate output; thus, commodity boom/bust is the cycle, to which fiscal policy responds. Since this model focuses on the oil price shock affecting the real oil output, the latter needs to be directly included in fiscal rules to ensure that fiscal policy transmits the shock into the economy. Acyclical fiscal policy assumes the zero oil output response of public spending and is taken as a benchmark to calculate loss in deviation from it; thus, the pro/countercyclical fiscal stance corresponds to the positive/negative oil output responses respectively. The impulse-response functions to a fall in world oil price shock, also referred to as an adverse terms of trade shock, are analyzed at flexible and rigid prices.

In section two, the model is outlined with its two types of households, standard optimizers and rule-of-thumb households, non-oil firms acting in a monopolistically competitive market, oil sector owned by the foreigners and government, two monetary policy rules for two instruments, and respective fiscal policy rules. Section three describes the model calibration. Section four examines the main results followed by the conclusion. 


\section{Model}

The model has several frictions: an incomplete asset market, investment adjustment costs, collateral constraint, and the Calvo price setting. The crucial underlying assumption is that the rest of the world is a saver, while the domestic economy is a borrower; thus, the foreign discount factor is higher than the domestic discount factor, as the domestic households might be relatively impatient compared to the rest of the world. This assumption implies in turn that the interest rate of an emerging economy is always higher than the foreign interest rate, which is consistent with the evidence (Reinhart \& Reinhart, 2008). The following subsections describe in detail the model structure.

\subsection{Households}

The economy is populated by a continuum of households on the interval $[0,1]$, where the fraction $\mu$ is rule-of-thumb households. They do not have access to financial markets and consume all of their disposable income each period. The other $(1-\mu)$ fraction of households are forward-looking households who hold government bonds, borrow from abroad, invest in non-oil physical capital, rent the capital to non-oil firms, and receive profits from those monopolistic non-oil firms. The labor market is competitive, wage is the same across all households, and both types of households work the same number of hours. The superscript $S$ indicates a variable associated with savers (forward-looking households), while $N$ is for non-savers (rule-of-thumb households).

The forward-looking household maximizes its utility (Schmitt-Grohe \& Uribe, 2003):

$$
E_{0} \sum_{t=0}^{\infty} \beta^{t} \frac{\left[C_{t}^{S}-\phi^{-1} N_{t}^{\phi}\right]^{1-\sigma}-1}{1-\sigma}, \quad \phi>1, \sigma>1
$$

subject to the following budget constraint:

$$
C_{t}^{S}+I_{t}+b_{t}+R_{t-1}^{*} \frac{R E R_{t}}{R E R_{t-1}} \frac{b_{t-1}^{*}}{\pi_{t}^{*}}+T_{t}^{S}=W_{t} N_{t}+R_{t}^{k n o} K_{t-1}^{n o}+R_{t-1} \frac{b_{t-1}}{\pi_{t}}+b_{t}^{*}+\Pi_{t}
$$

where $b_{t}=\frac{B_{t}}{P_{t}}$ is the real purchase of government bonds, $R E R_{t}$ is a CPI-based real 
exchange rate (the price of a foreign goods basket in terms of the domestic goods basket), $b_{t}^{*}=R E R_{t} \frac{B_{t}^{*}}{P_{t}^{*}}$ is the real foreign borrowings expressed in domestic goods (all foreign variables are denoted by an asterisk), $R_{t-1}$ and $R_{t-1}^{*}$ are the nominal gross domestic and foreign interest rates respectively, $T_{t}^{S}$ is the real lump-sum taxes, $W_{t}$ is a real wage, $R_{t}^{k n o}$ is the real rental cost of non-oil physical capital, $\pi_{t}=\frac{P_{t}}{P_{t-1}}$ is inflation, and $\Pi_{t}$ is the real profits of monopolistic non-oil firms ${ }^{3}$.

The law of motion for non-oil capital is specified according to Berg, Portillo, Yang, and Zanna (2013), incorporating the investment adjustment costs:

$$
K_{t}^{n o}=(1-\delta) K_{t-1}^{n o}+\left[1-\frac{\kappa}{2}\left(\frac{I_{t}}{I_{t-1}}-1\right)^{2}\right] I_{t}, \quad \text { where } \kappa>0
$$

The collateral constraint relates gross foreign liabilities to a future value of capital (Faia \& Iliopulos, 2011) and always binds, assuming that foreign debt is permanently high in this economy ${ }^{4}$ :

$$
R_{t}^{*} b_{t}^{*}=E_{t}\left\{\Omega \frac{Q_{t+1} \pi_{t+1}^{*}}{R E R_{t+1} / R E R_{t}} K_{t}^{n o}\right\}
$$

where $Q_{t}$ is a real shadow value of capital (Tobin's $\mathrm{Q}$ ) and $\Omega$ is an upper bound of leverage ratio.

The problem of the saver is, therefore, to maximize its utility (1) with respect to consumption $C_{t}^{S}$, investment $I_{t}$, capital $K_{t}^{n o}$, government bonds holdings $b_{t}$, foreign borrowings $b_{t}^{*}$, and hours worked $N_{t}$ subject to the budget constraint (2), capital accumulation equation (3), and collateral constraint (4). The first-order conditions of this problem are in Appendix C.

The rule-of-thumb household has the same preferences as the saver. It chooses only consumption and labor and its budget constraint is simply this:

$$
C_{t}^{N}+T_{t}^{N}=W_{t} N_{t}
$$

\footnotetext{
${ }^{3} \Pi_{t}=Y_{t}^{n o}\left(p_{h, t}-M C_{t}\right)$, where $Y_{t}^{n o}$ is non-oil output, $p_{h, t}$ is the relative domestic price of non-oil goods to composite consumption, and $M C_{t}$ is the real marginal costs of non-oil firms.

${ }^{4}$ Occasionally binding collateral constraint is ruled out because it requires global solution methods that may be infeasible to apply in this complex model.
} 
Each $i \in\{S, N\}$ type of household has the composite CES consumption preferences over domestic and foreign goods with $\eta>0$ as an elasticity of substitution between goods:

$$
C_{t}(i)=\left[\gamma^{\frac{1}{\eta}} C_{H, t}^{\frac{\eta-1}{\eta}}(i)+(1-\gamma)^{\frac{1}{\eta}} C_{F, t}^{\frac{\eta-1}{\eta}}(i)\right]^{\frac{\eta}{\eta-1}},
$$

where $\gamma$ is a home-bias parameter, while $(1-\gamma)$ is a degree of openness. The standard consumption expenditures minimization by a household delivers the following CPI index:

$$
P_{t}^{1-\eta}=\gamma P_{h, t}^{1-\eta}+(1-\gamma) P_{f, t}^{1-\eta} \text { or } 1=\gamma p_{h, t}^{1-\eta}+(1-\gamma) R E R_{t}^{1-\eta}
$$

where $p_{h, t}$ is a relative price of domestic goods to composite consumption and $R E R_{t}$ is also a relative price of foreign goods to composite consumption.

The aggregate consumption in turn is $C_{t}=\mu C_{t}^{N}+(1-\mu) C_{t}^{S}$. Similar to private consumption, investment is the CES basket with the same home-bias parameter $\gamma$ and CPI for simplicity.

\section{$2.2 \quad$ Firms}

Following Gali, Lopez-Salido, and Valles (2007), there are monopolistically competitive non-oil firms producing differentiated intermediate goods, and a perfectly competitive non-oil firm producing a final domestic good. The final domestic non-oil producer has a constant returns technology:

$$
Y_{t}^{n o}=\left(\int_{0}^{1} X_{t}(j)^{\frac{\varepsilon-1}{\varepsilon}} d j\right)^{\frac{\varepsilon}{\varepsilon-1}}
$$

where $X_{t}(j)$ is the input amount of intermediate good $j$ and $\varepsilon>1$ is the elasticity of substitution between differentiated intermediate goods. It maximizes profit taking as given the domestic final good's price $P_{t}^{h}$ and intermediate goods' prices $P_{t}^{h}(j)$ such that 
the optimal demand allocation is as follows:

$$
X_{t}(j)=\left(\frac{P_{t}^{h}(j)}{P_{t}^{h}}\right)^{-\varepsilon} Y_{t}^{n o}
$$

Each intermediate goods non-oil firm has an identical Cobb-Douglass production function, which includes the non-oil private capital, labor, and public capital:

$$
Y_{t}^{n o}(j)=u^{n o} K_{t-1}^{n o}(j)^{\alpha} N_{t}(j)^{1-\alpha} K_{G, t-1}^{\psi}
$$

where the level of technology $u^{n o}$ is just constant and the usage of public capital is common to all firms.

Intermediate goods producers solve their problem in two stages. First, cost minimization subject to the production function (8) provides the following real marginal costs common to all non-oil firms, taking the real wage and rental cost of capital as given:

$$
M C_{t}=\frac{W_{t}^{1-\alpha}\left(R_{t}^{k n o}\right)^{\alpha}}{u^{n o} K_{G, t-1}^{\psi}(1-\alpha)^{1-\alpha} \alpha^{\alpha}}
$$

Second, intermediate non-oil producers choose the price $P_{t}^{\text {hop }}$ to maximize their discounted real profits:

$$
\sum_{m=0}^{\infty} \theta^{m} E_{t}\left\{D_{t, t+m} Y_{t+m}^{n o}(j)\left(\frac{P_{t}^{h o p}}{P_{t+m}^{h}}-M C_{t+m}\right)\right\}
$$

where $D_{t, t+m}=\beta^{m} E_{t}\left(\frac{U_{C_{t+m}^{S}}}{U_{C_{t}^{S}}}\right)$ is a stochastic discount factor coming from the forwardlooking household's problem, subject to the demand constraint according to (7):

$$
Y_{t+m}^{n o}(j)=\left(\frac{P_{t}^{h o p}}{P_{t+m}^{h}}\right)^{-\varepsilon} Y_{t+m}^{n o}
$$

A fraction $(1-\theta)$ of non-oil firms adjusts their prices each period, while the respective fraction $\theta$ keeps their prices unchanged; thus, $\theta$ is an index of price stickiness according 
to Calvo (1983). The domestic price index evolves as follows:

$$
\left(P_{t}^{h}\right)^{1-\varepsilon}=\theta\left(P_{t-1}^{h}\right)^{1-\varepsilon}+(1-\theta)\left(P_{t}^{h o p}\right)^{1-\varepsilon}
$$

The first-order condition of this price setting decision (10) is below:

$$
\sum_{m=0}^{\infty} \theta^{m} E_{t}\left\{D_{t, t+m} Y_{t+m}^{n o}(j)\left(\frac{P_{t}^{h o p}}{P_{t+m}^{h}}-\frac{\varepsilon}{\varepsilon-1} M C_{t+m}\right)\right\}=0
$$

where $\frac{\varepsilon}{\varepsilon-1}$ is a frictionless price markup.

The production function of an oil firm has only capital input, assuming that oil production is a capital-intensive sector, and to avoid any complications originating from the possible labor mobility between two sectors:

$$
Y_{t}^{o}=\left(K_{t-1}^{o}\right)^{\alpha^{o}}
$$

The oil capital is accumulated by FDI which responds to the world oil price:

$$
\begin{gathered}
K_{t}^{o}=(1-\delta) K_{t-1}^{o}+F D I_{t}^{*} \\
\widehat{F D I_{t}^{*}}=\rho_{F D I} \widehat{F D I_{t-1}^{*}}+\left(1-\rho_{F D I}\right) \widehat{P_{t}^{o *}}
\end{gathered}
$$

Hats, hereafter, denote the deviation of variables from their steady state.

The world oil price follows the AR(1) process and has an exogenous shock referred to as the terms of trade shock:

$$
\widehat{P_{t}^{o *}}=\rho_{o} \widehat{P_{t-1}^{o *}}+\epsilon_{t}^{o}
$$

The oil firm receives its profits $\Pi_{t}^{o *}$ net of royalties levied on production quantity at a rate $\tau^{o}$ :

$$
\Pi_{t}^{o *}=\left(1-\tau^{o}\right) P_{t}^{o *} Y_{t}^{o}
$$

The oil sector is owned by the foreigners and the government. The dividend share of oil 
profits that the government receives is denoted by $\iota^{\mathrm{div}}$.

\subsection{Fiscal policy}

The government collects its lump-sum taxes $T_{t}$ and oil revenues $O R_{t}$ as the transfers from the SWF. It issues one-period bonds to finance the government purchases, which include public consumption $G_{t}^{C}$ and public investment $G_{t}^{I}$. The government budget constraint in real terms is as follows:

$$
(1-\mu) b_{t}+T_{t}+\underbrace{\left(\frac{R_{t-1}^{*}}{\pi_{t}^{*}}-\rho_{s w f}\right) S W F_{t-1}^{*} R E R_{t}}_{O R_{t}}=p_{t}^{g}\left(G_{t}^{C}+G_{t}^{I}\right)+(1-\mu) R_{t-1} \frac{b_{t-1}}{\pi_{t}},
$$

where $T_{t}=(1-\mu) T_{t}^{S}+\mu T_{t}^{N}$ and $p_{t}^{g}$ is a relative price of government purchases to composite consumption with its own home-bias parameter $\gamma_{2}$.

$$
p_{t}^{g}=\left[\gamma_{2} p_{h, t}^{1-\eta}+\left(1-\gamma_{2}\right) R E R_{t}^{1-\eta}\right]^{\frac{1}{1-\eta}}
$$

Public investment is productive so that the law of motion for public capital is given by:

$$
K_{t}^{G}=\left(1-\delta^{g}\right) K_{t-1}^{G}+G_{t}^{I}
$$

Oil tax revenues, denominated in foreign goods, consist of royalties and government share of the oil sector's profits

$$
T_{t}^{o *}=\tau^{o} P_{t}^{o *} Y_{t}^{o}+\iota^{\operatorname{div}} \Pi_{t}^{o *}
$$

which go directly to the SWF, accumulated according to the equation below.

$$
S W F_{t}^{*}=\rho_{s w f} S W F_{t-1}^{*}+T_{t}^{o *}
$$

where $\rho_{s w f}$ is a persistence in the SWF process, assuming that $\left(1-\rho_{s w f}\right)$ fraction of SWF is used for its auditing or constitutes its investment loss. 
Two fiscal instruments, public investment and public consumption, have the following rules, with their oil output response $\left(\vartheta_{G I}\right.$ and $\left.\vartheta_{G C}\right)$ associated with fiscal cyclicality:

$$
\begin{gathered}
\widehat{G_{t}^{I}}=\rho_{G I} \widehat{G_{t-1}^{I}}+\left(1-\rho_{G I}\right)\left[\vartheta_{G I} \widehat{Y_{t}^{o}}-\gamma_{G I} \widehat{b}_{t-1}+\gamma_{O R}^{G I} \widehat{O R}_{t}\right] \\
\widehat{G_{t}^{C}}=\rho_{G C} \widehat{G_{t-1}^{C}}+\left(1-\rho_{G C}\right)\left[\vartheta_{G C} \widehat{Y_{t}^{o}}-\gamma_{G C} \widehat{b}_{t-1}+\gamma_{O R}^{G C} \widehat{O R}_{t}\right]
\end{gathered}
$$

This specification of referring pro/counter/acyclical fiscal policy to positive/negative/zero values for $\vartheta_{G I}$ and $\vartheta_{G C}$ respectively is consistent with a notion of cyclically adjusted or structural fiscal balances, according to which a cyclical component, related to automatic stabilizers, should be removed mostly from taxes and transfers, while public spending on wages, goods, and services is usually independent of the business cycle, thus not requiring any adjustment (Bornhorst et al., 2011).

Since fiscal debt clears the government budget constraint, the lump-sum taxes need a separate equation, which includes fiscal debt, public spending similar to Gali, LopezSalido, and Valles (2007), and oil revenues specific to this model:

$$
\widehat{T}_{t}=\varphi_{b} \widehat{b}_{t-1}+\varphi_{I} \widehat{G_{t}^{I}}+\varphi_{C} \widehat{G_{t}^{C}}-\varphi_{O R} \widehat{O R}_{t}
$$

\subsection{Monetary policy}

The nominal interest rate responds to its lagged value, CPI inflation, and aggregate output according to the CPI targeting Taylor rule below:

$$
\widehat{R}_{t}=\rho \widehat{R}_{t-1}+(1-\rho)\left[\phi_{\pi} \pi_{t}+\phi_{y} \widehat{Y}_{t}\right]
$$

where $\rho$ is an interest rate smoothing parameter, $\phi_{\pi}$ and $\phi_{y}$ are inflation and output responses respectively.

The PPT Taylor rule, in contrast, uses the product price inflation, which is a weighted average of oil price inflation in real terms $\pi_{t}^{o}=\Delta \widehat{P}_{t}^{o *}+\triangle \widehat{R E R} t$ and domestic price inflation $\pi_{t}^{h}=\pi_{t}-\frac{1-\gamma}{\gamma} \triangle \widehat{R E R}_{t}$, according to Appendix E, with weights corresponding 
to the GDP share of the oil $s_{o}$ and non-oil $\left(1-s_{o}\right)$ sectors respectively:

$$
\widehat{R}_{t}=\rho \widehat{R}_{t-1}+(1-\rho)\left[\phi_{\pi}\left(s_{o} \pi_{t}^{o}+\left(1-s_{o}\right) \pi_{t}^{h}\right)+\phi_{y} \widehat{Y}_{t}\right]
$$

A managed exchange rate regime is associated with the foreign exchange interventions as an additional monetary policy instrument. They represent the purchases/selling of foreign currency by a central bank, and accumulate the foreign exchange reserves according to their separate rule (Benes et al., 2015), responding to the exchange rate and its rate of depreciation ${ }^{5}$.

$$
\widehat{f x r_{t}^{*}}=\rho_{f x r} \widehat{f x r_{t-1}^{*}}+\left(1-\rho_{f x r}\right)\left(\alpha_{1} \widehat{R E R}+\alpha_{2} \Delta \widehat{R E R} \widehat{R}_{t}\right), \quad \alpha_{1}<0, \alpha_{2}<0,
$$

where $f x r_{t}^{*}=R E R_{t} \frac{F X R_{t}^{*}}{P_{t}^{*}}$ is the real foreign exchange reserves expressed in domestic goods. This rule shows that the more the exchange rate depreciates/appreciates, the more the foreign exchange reserves fall/accumulate, implying the selling/purchases of foreign currency by a central bank respectively.

According to Benes et al. (2015), the foreign exchange reserves affect the exchange rate through the interest rate: when the reserves accumulate, the foreign liabilities of a financial sector increase, thus its exposure to the exchange rate risk rise, causing high risk premia that results in the depreciated exchange rate. This mechanism is in place due to the uncovered interest rate parity (UIP) condition, which directly includes the reserves, yet it is specified ad hoc by Benes et al. (2015). This model, in contrast, allows the UIP to be derived from the first-order conditions of the forward-looking household, who borrows from abroad to invest domestically and has the collateral constraint, thanks to which the reserves explicitly appear in the UIP equation and also in private investment, supporting the same mechanism (see Appendix C for details and the log-linearized equations 43, 50).

A flexible exchange rate regime implies the zero values for $\alpha_{1}$ and $\alpha_{2}$ parameters in the foreign exchange reserves rule (27).

\footnotetext{
${ }^{5}$ The higher $\widehat{R E R}_{t}$, the more the real exchange rate depreciates.
} 


\subsection{Market clearing conditions}

For simplicity, an elasticity of substitution between domestic and foreign goods is assumed to approach one $(\eta \rightarrow 1)$; thus, the domestic non-oil goods market clearing condition is as follows:

$$
p_{t}^{h} Y_{t}^{n o}=\gamma\left[C_{t}+(1-\mu) I_{t}\right]+\gamma_{2} p_{t}^{g}\left(G_{t}^{C}+G_{t}^{I}\right)
$$

The real GDP on its supply and demand sides is:

$$
p_{t}^{h} Y_{t}^{n o}+Y_{t}^{o} P_{t}^{o *} R E R_{t}=C_{t}+(1-\mu) I_{t}+p_{t}^{g}\left(G_{t}^{C}+G_{t}^{I}\right)+N X_{t}
$$

The labor and capital markets clear according to their conditions:

$$
N_{t}=\int_{0}^{1} N_{t}(j) d j, \quad K_{t}^{n o}=\int_{0}^{1} K_{t}^{n o}(j) d j
$$

The balance of payments equates its current account with the financial account. The current account includes net exports, interest income of SWF assets (as those assets are saved abroad) minus the foreign share of the oil sector's profits, while the financial account represents the interest payments on foreign debt, a new foreign borrowing of households, and FDI.

$$
\begin{aligned}
& N X_{t}+\left(\frac{R_{t-1}^{*}}{\pi_{t}^{*}}-\rho_{s w f}\right) S W F_{t-1}^{*} R E R_{t}-\left(1-\iota^{\mathrm{div}}\right) R E R_{t} \Pi_{t}^{o *}= \\
& =(1-\mu)\left(R_{t-1}^{*} \frac{R E R_{t}}{R E R_{t-1}} \frac{b_{t-1}^{*}}{\pi_{t}^{*}}-b_{t}^{*}\right)-R E R_{t} F D I_{t}^{*}
\end{aligned}
$$

\subsection{The rest of the world}

The rest of the world is a large economy governed by three exogenous equations below:

$$
\begin{gathered}
\widehat{Y}_{t}^{*}=\rho_{Y^{*}} \widehat{Y}_{t-1}^{*}+\epsilon_{t}^{Y^{*}} \\
\widehat{R_{t}^{*}}=\phi_{\pi}^{*} \pi_{t}^{*}+\phi_{y}^{*} \widehat{Y}_{t}^{*} \\
\pi_{t}^{*}=\beta^{*} E_{t} \pi_{t+1}^{*}+\lambda^{*}\left(\sigma+\frac{\phi^{*}+\alpha^{*}}{1-\alpha^{*}}\right) \widehat{Y}_{t}^{*}
\end{gathered}
$$


The equilibrium of this model consists of households' and firms' optimality conditions (41, 42, 43, 45, and 50), capital accumulation equations (46, 47, and 48), SWF accumulation (49), outputs (51,52, and 53), the government budget constraint (54), fiscal policy $(22,23$, and 24$)$, monetary policy (25 or 26 and 27$)$, the balance of payments (44), FDI process (14), market clearing conditions (56 and 57), price equations (15, 40, and 55), and the rest of the world (30, 31, and 32).

\section{Calibration}

All parameters can be divided into three sets: standard values borrowed from other studies because of the non-availability of relevant data, estimates from time-series regressions according to the model's equations, and calibrated parameters based on a steady state of the model. The list of parameters is provided in Appendix A, excluding the GDP ratios and parameters for the rest of the world which are described in this section.

The first set includes the depreciation rates for private and public capital $\delta=0.025$, $\delta^{g}=0.02$ (Traum \& Yang, 2011), the elasticity of substitution between differentiated intermediate goods $\varepsilon=9$ (Gali, 2015), price stickiness $\theta=0.9$ (Jakab \& Vilagi, 2008), the inverse of intertemporal elasticity of substitution for consumption $\sigma=2$ (Schmitt-Grohe \& Uribe, 2003), investment adjustment costs parameter $\kappa=20$ (Berg, Portillo, Yang \& Zanna, 2013), and the fiscal debt response of lump-sum taxes $\varphi_{b}=0.4$ (Algozhina, 2012). The foreign parameters are set to their standard values: the elasticity of wages with respect to hours worked $\phi^{*}=1.45$ (Schmitt-Grohe \& Uribe, 2003), discount factor $\beta^{*}=0.99$, inflation and output responses in the Taylor rule $\phi_{\pi}^{*}=1.5, \phi_{y}^{*}=0.125$ (Gali, 2015), price stickiness $\theta^{*}=0.75$ (Gali, Lopez-Salido \& Valles, 2007), output elasticity to capital $\alpha^{*}=0.32$, and output persistence $\rho_{Y^{*}}=0.8$.

The second set consists of significant OLS estimates according to the model's equations based on Kazakh data described in Appendix B. If a time series exhibits a seasonal pattern, a fourth difference of quarterly data is used; otherwise, a first difference is used to make data stationary. In particular, a fourth difference of the log of real public consumption is 
regressed on its lagged value, first difference of the log of oil output, first difference of the log of lagged real public debt, and real oil revenues of the government budget according to the public consumption rule (23). The estimates are as follows, with t-statistics in parenthesis, suggesting the only significant autoregressive coefficient $\rho_{G C}=0.33$, which is also set for a persistence in public investment, $\rho_{G I}=0.33$.

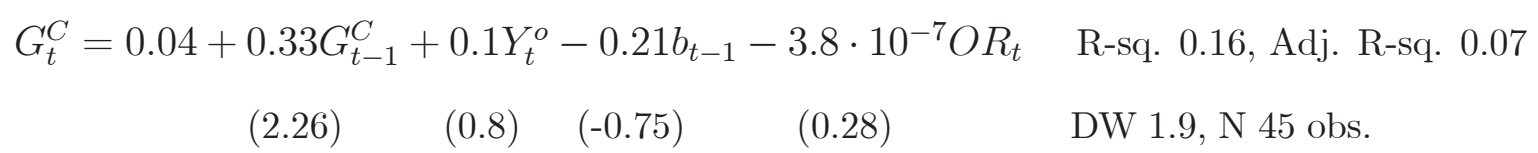

The parameters of foreign exchange reserves equation (27) are obtained by running two regressions. The first is based on the Hodrick-Prescott (HP) filter to remove trends in the real foreign exchange reserves and real exchange rate; thus, a cycle component of the log of real foreign exchange reserves is regressed on its lagged value, cycle component of the log of real exchange rate, and first difference of the log of real exchange rate. The significant estimates include the persistence parameter $\rho_{f x r}=0.57$ and the exchange rate response $\alpha_{1}=-0.47$.

1) $f x r_{t}^{*}=-0.005+0.57 f x r_{t-1}^{*}-0.47 R E R_{t}+0.32 \triangle \ln R E R_{t}$

$$
\begin{aligned}
& \text { R-sq. 0.51, Adj. R-sq. } 0.49 \\
& \text { DW 1.99, N } 69 \text { obs. }
\end{aligned}
$$

The second regression uses a first difference in the real foreign exchange reserves, which is run on its lagged value and first difference of the log of real exchange rate. As a result, the exchange rate change response $\alpha_{2}$ is suggested to be -0.6 .



These values for $\alpha_{1}$ and $\alpha_{2}$ apply to a managed exchange rate regime supported by the foreign exchange interventions as an additional monetary policy instrument, whereas they are set to zero if a flexible exchange rate regime is examined.

The world oil price equation (15) corresponds to its empirical counterpart based on a cycle component of the log of world oil price, which is produced by the HP. Therefore, a persistence in the oil price process $\rho_{o}$ is 0.74 , while a standard deviation of the world oil price shock is 0.14 . 


$$
\begin{aligned}
& P_{t}^{o *}=0.002+0.74 P_{t-1}^{o *}+\epsilon_{t}^{o} \quad \text { R-sq. 0.55, Adj. R-sq. } 0.54 \\
& \text { (9.33) (s.d. 0.14) DW 1.35, N } 73 \text { obs. }
\end{aligned}
$$

As for the FDI equation (14), the logs of real FDI and world oil price data appear to be cointegrated based on both cointegration tests: Engel-Granger and Johansen. Since an error correction VAR specification is inappropriate to match with the model's equation, a long run OLS regression is used: the log of real FDI is regressed on its lagged value and $\log$ of world oil price. Given a significant effect of world oil price, the FDI persistence appears to be $0.2, \rho_{F D I}=1-0.8=0.2$.



The third set includes the parameters calibrated to a steady state of the model which corresponds to data averages ${ }^{6}$. The GDP ratios of consumption, public consumption, net exports, FDI, foreign debt, fiscal debt, oil output, and public investment are as follows respectively: $c_{y}=0.61, g_{y}^{C}=0.08, n x_{y}=0.07, f d i_{y}=0.09, b_{y}^{*}=2.17, b_{y}=0.5$, $s_{o}=0.52$, and $g_{y}^{I}=0.07$. The degree of openness is calculated as a ratio of imports to GDP, $1-\gamma=0.32$; thus, the home-bias parameter in private consumption and investment $\gamma$ is equal to 0.68 , while it is assumed to be higher for public spending $\gamma_{2}=0.9$, as its large share may go to the wages of public servants. The domestic discount factor is around 0.978 because the average T-bill rate is used as a proxy for the policy interest rate, 2.3 percent per quarter ${ }^{7}$. The upper bound of leverage ratio $\Omega$ appears to be 0.54 . The elasticity of output with respect to private capital $\alpha$ is equal to 0.3 as a share of capital income to GDP, while with respect to public capital it is $\psi=0.16$ suggested by a steady state wage equation in Appendix D. Using data on wages, the elasticity of wages with respect to hours worked $\phi$ is 1.45 according to the labor supply condition (38), in which hours are obtained from the non-oil production function (8). The royalties rate levied on oil production quantity $\tau^{o}=0.27$ is calculated as the SWF inflows share in oil output.

\footnotetext{
${ }^{6}$ The steady state is natural and inefficient in Appendix D, since it is at flexible prices and with monopolistic competition.

${ }^{7}$ The domestic interest rate matters for the government bonds in this model, as investments are financed by foreign funds rather than the domestic financial market.
} 
The dividend share of oil profits that the government receives $\iota^{\mathrm{div}}$ is set to 0.05 , while the elasticity of oil output with respect to oil capital $\alpha^{o}$ is technically feasible at 0.7 . The persistence in SWF process $\rho_{\text {swf }}$ is equal to 0.755 to match the GDP ratio of SWF assets $s w f_{y}=0.65$. The interest rate smoothing $\rho$ in the Taylor rule is set to 0.95 .

There are three types of fiscal policy: procyclical, countercyclical, and acyclical. The acyclical fiscal policy is a benchmark to calculate welfare loss in deviation from it. It is associated with the zero oil output response of public consumption and public investment in their rules $\left(\vartheta_{G C}=0\right.$ and $\left.\vartheta_{G I}=0\right)$. The procyclical fiscal policy corresponds to the positive oil output response of public spending $\left(\vartheta_{G C}=0.3\right.$ and $\left.\vartheta_{G I}=0.3\right)$, while the countercyclical fiscal policy is simulated at their negative values $\left(\vartheta_{G C}=-0.3\right.$ and $\left.\vartheta_{G I}=-0.3\right)$. Those are the two parameters which differ across fiscal cyclicality, while the rest hold the same. The fiscal debt responses of public consumption $\gamma_{G C}=0.3$ and public investment $\gamma_{G I}=0.3$ are assumed to be equal. The response of public consumption to fiscal oil revenues $\gamma_{O R}^{G C}$ is set to 0.2 , fixing it slightly lower than $\vartheta_{G C}=0.3$, whereas public investment response to the oil revenues $\gamma_{O R}^{G I}$ is 0.1 . The parameters of the lumpsum taxes equation (24) are as follows: public consumption response $\varphi_{C}=1$, public investment response $\varphi_{I}=0.2$, and oil revenues response $\varphi_{O R}=-0.3$. The latter is calculated according to taxes at a steady state and assures non-zero inflation and output responses of the PPT Taylor rule under acyclical fiscal policy:

$$
\varphi_{O R}=\frac{\varphi_{b} \ln \bar{b}+\varphi_{I} \ln \overline{G_{I}}+\varphi_{C} \ln \overline{G_{C}}-\ln \bar{T}}{\ln \overline{O R}}
$$

\section{Results}

This section describes results in a following order. The welfare measure according to De Paoli (2009) is explained, based on which a grid search of monetary policy parameters is made. Given these optimal parameters, the model has been simulated with essentially two shocks of 0.14 standard deviations for both: the world oil price and foreign output shocks. The impulse-response functions to the world oil price shock only, interpreted as a terms 
of trade shock, are analyzed at flexible and sticky prices. The welfare loss components, having equal weights and then weights according to De Paoli (2009), are examined across fiscal policy cyclicality, exchange rate regimes, and monetary policy's price anchors.

In a small open economy with monopolistic competition and nominal rigidities, De Paoli (2009) has used a linear-quadratic approach to derive welfare as a second-order approximation of households' utility. The linear terms in this objective function have been eliminated by a second-order approximation of her model's equilibrium conditions in order to take into account the effect of second moments on the mean of the variables. As a result, the objective loss function becomes a purely quadratic expression of domestic price inflation, output gap, and real exchange rate.

In this model, such a loss measure, represented as a sum with equal weights ${ }^{8}$ of variances in domestic price inflation $\pi_{t}^{h}$, aggregate output $\widehat{Y}_{t}$, and real exchange rate $\widehat{R E R}$, is used to search the two parameters of the Taylor rule: inflation $\phi_{\pi}$ and output responses $\phi_{y}$ across pro/counter/acyclical fiscal stance. Monetary policy can be hybrid, combining a managed exchange rate regime with a $\mathrm{CPI} / \mathrm{PPT}$ anchor, or pure inflation targeting associated with the CPI/PPT under a flexible exchange rate regime. The CPI Taylor rule (25) is defined above, while the PPT Taylor rule (26) boils down to:

$$
\widehat{R}_{t}=\rho \widehat{R}_{t-1}+(1-\rho)\left[\phi_{\pi}\left(s_{o} \Delta \widehat{P}_{t}^{o *}+\left(1-s_{o}\right) \pi_{t}+\frac{s_{o}-1+\gamma}{\gamma} \Delta \widehat{R E R} t\right)+\phi_{y} \widehat{Y}_{t}\right]
$$

The results of grid search show that the optimal CPI inflation response is 0.9 , while the PPT inflation response is higher and equals 1.9 with the output response in both cases of 0.1 . These results stay the same across fiscal policy cyclicality and exchange rate regime $^{9}$. The output response appears to be close to its standard value of 0.125 commonly found in the literature (Gali, 2015) given that this search is in a range between 0 and 2

\footnotetext{
${ }^{8}$ The weights for loss components are chosen as ones, basically assuming that the domestic policymakers have equal stabilization goals over those components. As a sensitivity analysis, the weights differ in Table 2, following the parametrization of De Paoli (2009).

${ }^{9}$ The value of the CPI inflation response may question the Taylor principle at first. Yet this model is for a small open economy calibrated on quarterly rates, where the real exchange rate matters and there is a foreign exchange interventions rule, which affects the interest rate according to the UIP. Therefore, the standard Taylor principle at annual rates, associated with a closed economy framework, shouldn't be a benchmark in this model, which has a determinate solution according to the Blanchard-Kahn conditions.
} 
with a step of 0.1 for parameters. The inflation response of the PPT anchor is higher than CPI targeting because the PPT Taylor rule includes oil price inflation, which is volatile in the presence of oil price shock and needs to be properly stabilized to achieve the low variations in output and exchange rate as the components of loss function.

Using these optimized policy parameters, the impulse-response functions to a negative world oil price shock are analyzed at flexible prices first, to understand the real channels of transmission mechanism ${ }^{10}$. Figure 1 shows that a sudden drop of oil price depreciates the exchange rate because the cash-flows in foreign currency from oil exports decrease, creating the excessive supply of domestic currency, which results in its value loss. The depreciated exchange rate makes the imported goods expensive and the taxes higher, because of the increased oil revenues of the government budget in real terms, which discourage hours worked as labor income declines. The hours worked have a dominant effect on inflation due to the Phillips curve, so that production costs matter for inflation. Therefore, inflation drops significantly because of the reduced hours worked, causing in turn a decrease in interest rate due to the high inflation response in the Taylor rule. The reduced labor, as a main production input, contributes to a fall in non-oil output. Since non-oil output falls, requiring less private investment financed by foreign borrowings, the foreign debt also declines. As income is low, private consumption drops, decreasing domestic prices; thus, aggregate output also falls. Fiscal debt accumulates over time as automatic stabilizers suggest in the case of a recession. These dynamics are similar across countercyclical and acyclical fiscal policies under a managed exchange rate regime, regardless of CPI/PPT monetary rule.

Figure 1. Impulse-response functions at flexible prices: countercyclical/acyclical fiscal

\footnotetext{
${ }^{10}$ The flexible prices or no nominal rigidities version corresponds to a price stickiness parameter close to zero, $\theta=0.0001$. Yet at this value, a flexible exchange rate regime $\left(a_{1}=a_{2}=0\right)$ across fiscal cyclicality and CPI/PPT monetary anchors does not produce feasible solutions.
} 
policy combined with $\mathrm{CPI} / \mathrm{PPT}$ monetary rule under a managed exchange rate regime


A procyclical fiscal stance, in contrast, produces higher exchange rate depreciation, because public spending declines with a fall in oil output, putting fewer demands on domestic currency, thus exerting additional depreciating pressure on tenge. As a result, the foreign debt burden increases, taxes rise more, net exports are improved, and inflation drops less due to a pass-through effect from the depreciated exchange rate (see Figure 2 in comparison with Figure 1). Overall, the impulse-response functions at flexible prices suggest that the extent of exchange rate depreciation and its effects on foreign debt, taxes, net exports, and inflation depend on fiscal policy cyclicality, whereas monetary 
policy, across its CPI/PPT rule, does not change the real effects of the terms of trade shock which stay the same within a pro/counter/acyclical fiscal stance.

Figure 2. Impulse-response functions at flexible prices: procyclical fiscal policy combined with $\mathrm{CPI} / \mathrm{PPT}$ monetary rule under a managed exchange rate regime


Nominal rigidities alter the effect of a world oil price shock on the exchange rate, lump-sum taxes, and thereby fiscal debt as well. When prices are rigid, the exchange rate depreciation is delayed in all types of fiscal cyclicality. This is not only due to a price stickiness, but also because the SWF transfers are converted into domestic currency 
before being sent to the government budget, therefore demand on tenge increases, exerting a countervailing appreciating pressure and delaying the exchange rate depreciation in Figures 3 and 4 . Since the exchange rate does not respond immediately, taxes fall due to a recession, thus fiscal debt increases to finance public spending when revenues are low. Despite the delay of exchange rate depreciation, net exports are still improved at rigid prices, because private consumption goes down suggesting a decrease in imports.

Figure 3. Impulse-response functions with nominal rigidities: countercyclical/acyclical fiscal policy combined with CPI targeting monetary rule under a flexible/managed exchange rate regime
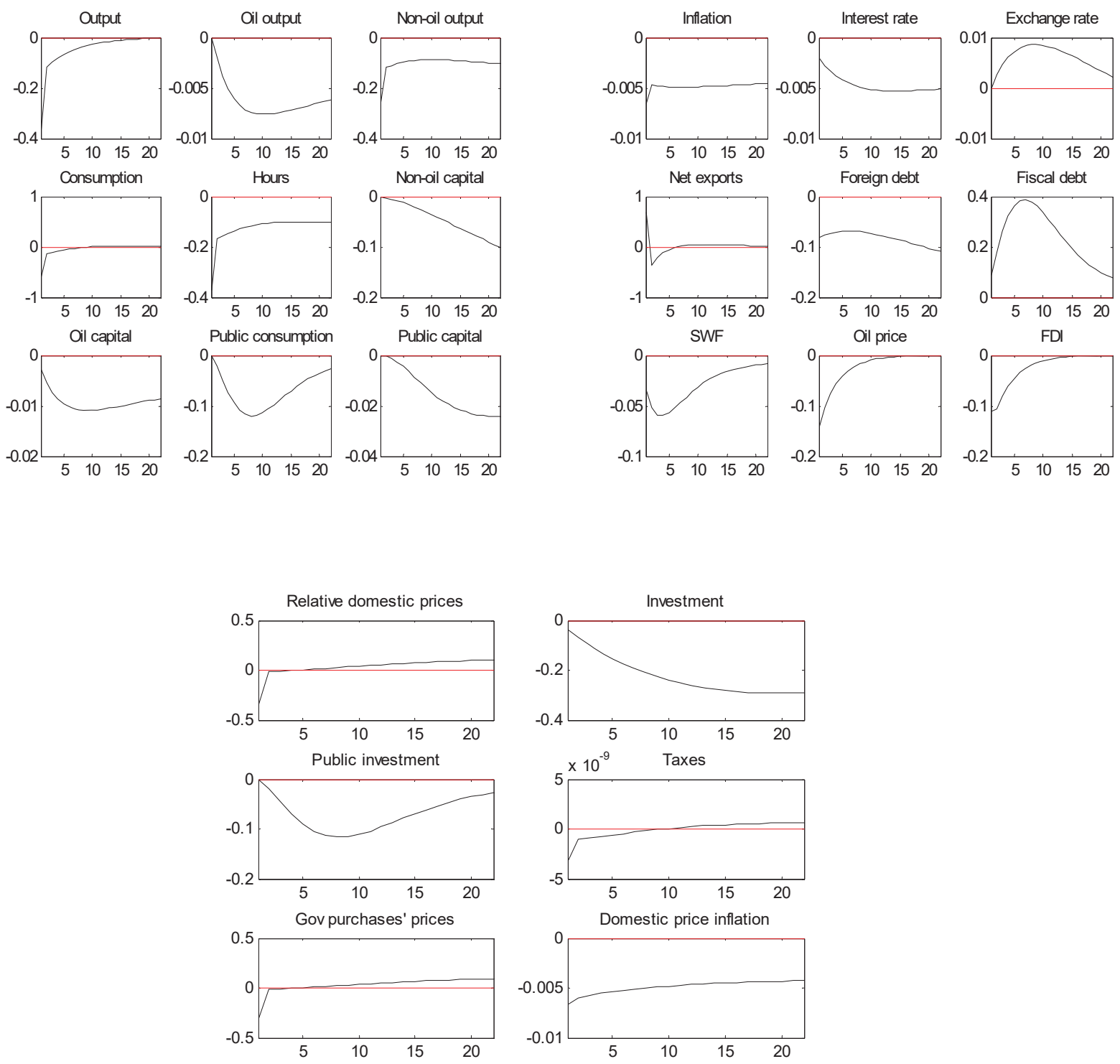
Figure 4. Impulse-response functions with nominal rigidities: procyclical fiscal policy combined with CPI targeting monetary rule under a flexible/managed exchange rate regime
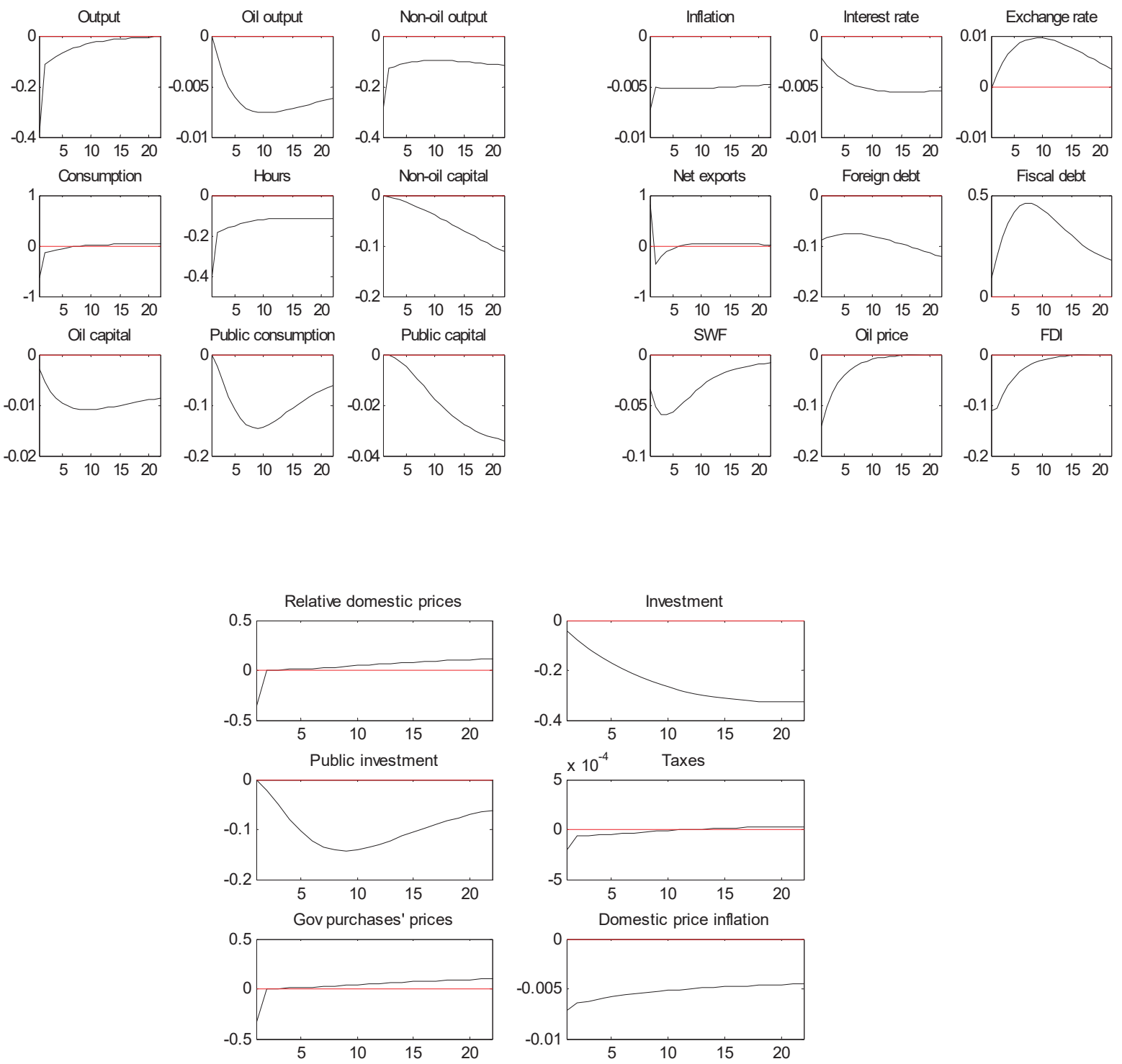

Sticky prices reduce the abrupt responses of inflation and interest rate, which is determined by the Taylor rule. Yet, since prices do not adjust immediately, there are larger real effects on outputs, consumption, and hours worked. Lump-sum taxes also decrease more, as a relatively severe recession produces fewer government revenues. Under a procyclical fiscal stance in Figure 4, public consumption and public investment, with its accumulated public capital, fall more over time than under a counter/acyclical fiscal policy in Figure 
3. This is because public spending in the former case goes down in tandem with the oil output, suggesting larger negative responses of fiscal instruments in the long run.

The same dynamics hold under a PPT monetary rule in Figures 5 and 6 respectively. Yet the exchange rate is more volatile over time compared to the CPI targeting, as shown in Figure 5 versus Figure 3 or Figure 6 in contrast to Figure 4. This is because a PPT monetary anchor includes oil price inflation, which explicitly involves the oil price shock.

Figure 5. Impulse-response functions with nominal rigidities: countercyclical/acyclical fiscal policy combined with PPT monetary rule under a flexible/managed exchange rate regime
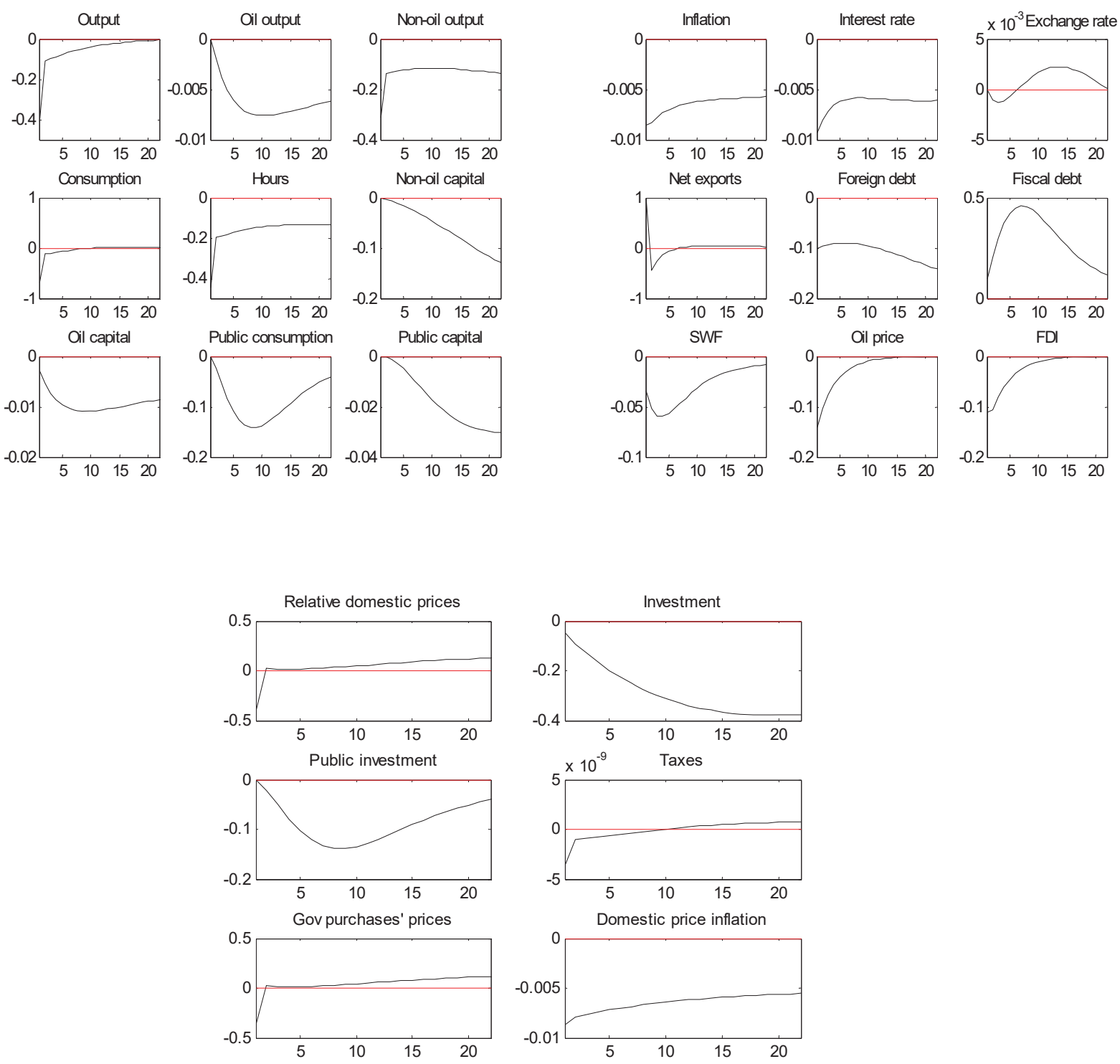
Figure 6. Impulse-response functions with nominal rigidities: procyclical fiscal policy combined with PPT monetary rule under a flexible/managed exchange rate regime
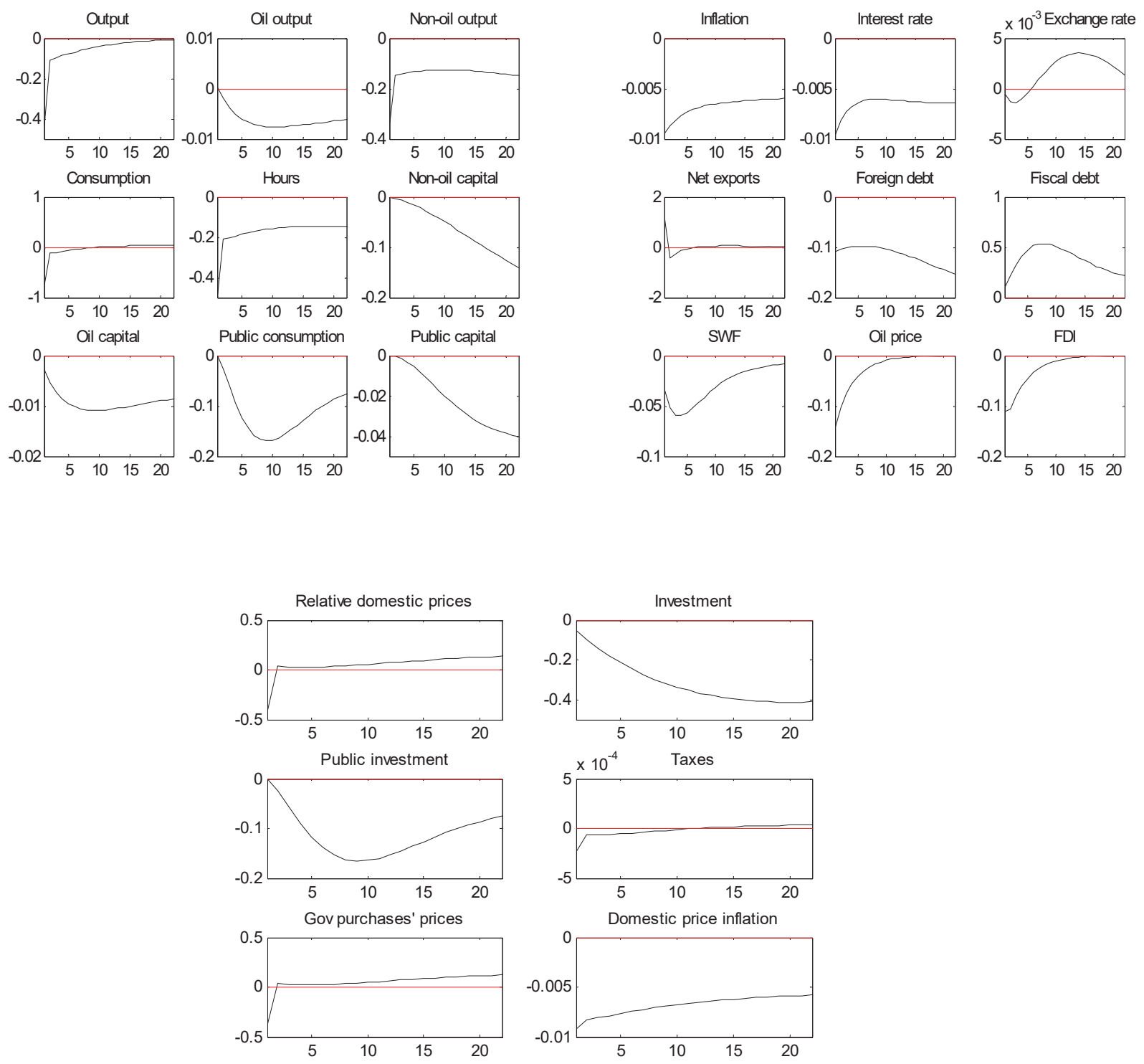

The impulse-response functions of the interest rate do not comply with Frankel and Catao (2011), who advocated the PPT because its interest rate would rise in response to a positive terms of trade shock, causing exchange rate appreciation, thus countercyclically offsetting the favorable shock. It appears that monetary policy parameters matter for the interest rate, but not CPI or PPT anchor per se, while the exchange rate tends to depreciate in response to an adverse terms of trade shock, but is not affected by the interest rate itself. Since the loss-minimizing inflation response is higher than the output 
response in the Taylor rule $\left(\phi_{\pi}=0.9\right.$ or 1.9 versus $\left.\phi_{y}=0.1\right)$, the interest rate increases to tighten the economy when there is inflation and falls to stimulate demand when inflation declines.

Table 1 summarizes the numerical results of loss measure $L$ as an equal summation of variances in domestic price inflation, aggregate output, and real exchange rate. The results are produced at the optimized Taylor rule's parameters for the model with nominal rigidities. All entries are in percent deviation from a benchmark policy combination: acyclical fiscal stance and a CPI monetary anchor under a flexible exchange rate regime, i.e., $\phi_{\pi}=0.9$ and $\phi_{y}=0.1$. Positive values mean the percentage increase in loss relative to the benchmark, while negative values indicate lower loss contributed by a respective entry.

Table 1. Loss components

\begin{tabular}{lcccc|cccc}
\hline \hline & \multicolumn{3}{c|}{ Procyclical fiscal policy } & \multicolumn{4}{c}{ Countercyclical fiscal policy } \\
\hline & Managed $R E R$ & \multicolumn{2}{c|}{ Flexible $R E R$} & Managed $R E R$ & \multicolumn{2}{c}{ Flexible $R E R$} \\
\hline & CPI & PPT & CPI & PPT & CPI & PPT & CPI & PPT \\
\hline \hline$L$ & 3.8 & 21.55 & 2.65 & 20.14 & 0.96 & 18.13 & -0.18 & 16.74 \\
$\operatorname{Var}\left(\pi_{t}^{h}\right)$ & 0.45 & 1.7 & 0.14 & 1.32 & 0.28 & 1.49 & -0.019 & 1.12 \\
$\operatorname{Var}\left(\widehat{Y}_{t}\right)$ & 2.59 & 12.32 & 1.42 & 10.82 & 1.12 & 10.52 & -0.021 & 9.06 \\
$\operatorname{Var}\left(\widehat{R E R_{t}}\right)$ & 0.76 & 7.53 & 1.09 & 8 & -0.44 & 6.12 & -0.14 & 6.56 \\
\hline \hline
\end{tabular}

\begin{tabular}{lcccc}
\hline \hline & \multicolumn{4}{c}{ Acyclical fiscal policy } \\
\hline & Managed $R E R$ & \multicolumn{2}{c}{ Flexible $R E R$} \\
\hline & CPI & PPT & CPI & PPT \\
\hline \hline$L$ & 1.13 & 18.3 & 0 & 16.92 \\
$\operatorname{Var}\left(\pi_{t}^{h}\right)$ & 0.3 & 1.5 & 0 & 1.14 \\
$\operatorname{Var}\left(\widehat{Y}_{t}\right)$ & 1.13 & 10.54 & 0 & 9.08 \\
$\operatorname{Var}\left(\widehat{R E R_{t}}\right)$ & -0.3 & 6.25 & 0 & 6.7 \\
\hline \hline
\end{tabular}


Values are in the percent deviation of corresponding entry from the benchmark acyclical fiscal policy combined with CPI targeting monetary rule under a flexible exchange rate regime.

Table 1 suggests that a countercyclical fiscal stance and CPI inflation monetary targeting under a flexible exchange rate regime is the best policy combination, delivering lower variances of variables than a benchmark does. This is because fiscal stimulus dampens a negative terms of trade shock by countercyclically offsetting it and stabilizing the ultimate effects on the economy. The CPI targeting monetary policy is preferred to a PPT rule, as the latter causes high volatility in all variables due to capturing the shock. CPI inflation includes the imported goods' prices in the form of a real exchange rate change, while PPT, instead, has the oil price inflation which is basically irrelevant for private consumption, being an exogenous term independent from domestic policies, and thus excluded from the loss measure. Therefore, the CPI monetary anchor produces a better outcome in terms of welfare loss, given that a small open economy, especially with its emerging market, is highly dependent on imported goods, whereas commodity exporting benefits are not broadly distributed among its domestic households.

The real exchange rate alone, though, is better stabilized under a managed exchange rate regime, yet a flexible exchange rate regime provides lower variances for the rest of the variables. This is because the latter case does not have the foreign exchange interventions associated with the central bank's foreign exchange reserves, which affect the interest rate according to the UIP (equation 50 in Appendix F), and they also influence private investment, due to the collateral constraint (equation 43 in Appendix F). A managed exchange rate regime, in contrast, involves those interventions to regulate the exchange rate, not letting it flexibly adjust according to market forces, and at the same time causing high variations in other variables due to the linkages indicated above.

Overall, Table 1 reports the following three findings, assuming equal unit weights for variances in the welfare loss. First, a countercyclical fiscal policy should be preferred to acyclical and procyclical fiscal stances across monetary rules and exchange rate regimes. In fact, a procyclical fiscal policy is the worst, because it transmits an external terms 
of trade shock to the domestic economy, without offsetting it in any way; essentially, the economy becomes dependent on volatile foreign shocks rather than staying resilient to them. Second, the CPI targeting monetary rule should be adopted by a commodity exporting country, rather than the PPT rule, in contrast to what Frankel and Catao (2011) recommend. This is because a countercyclical fiscal policy already acts against the volatile terms of trade shock, which was overlooked by Frankel and Catao (2011) who focused only on monetary policy. Third, a flexible exchange rate regime should be followed, consistent with a robust policy advice from various international institutions to central banks worldwide, because a managed exchange rate regime does not stabilize all other welfare-relevant variables, but only the exchange rate.

Table 2. Loss components: different weights

\begin{tabular}{lcccc|cccc}
\hline & \multicolumn{3}{c|}{ Procyclical fiscal policy } & \multicolumn{3}{c}{ Countercyclical fiscal policy } \\
\hline & Managed $R E R$ & Flexible $R E R$ & Managed $R E R$ & Flexible $R E R$ \\
\hline & CPI & PPT & CPI & PPT & CPI & PPT & CPI & PPT \\
\hline \hline Loss & 2.66 & 21.16 & 2.88 & 21.57 & -0.53 & 17.4 & -0.35 & 17.75 \\
$0.54 \operatorname{Var}\left(\pi_{t}^{h}\right)$ & 0.66 & 2.5 & 0.2 & 1.94 & 0.41 & 2.2 & -0.03 & 1.64 \\
$0.03 \operatorname{Var}\left(\widehat{Y}_{t}\right)$ & 0.21 & 1.01 & 0.12 & 0.88 & 0.09 & 0.86 & -0.002 & 0.74 \\
$0.86 \operatorname{Var}\left(\widehat{R E R_{t}}\right)$ & 1.79 & 17.65 & 2.56 & 18.75 & -1.03 & 14.34 & -0.32 & 15.37 \\
\hline \hline
\end{tabular}

\begin{tabular}{lcccc}
\hline \hline & \multicolumn{4}{c}{ Acyclical fiscal policy } \\
\hline & Managed $R E R$ & \multicolumn{2}{c}{ Flexible $R E R$} \\
\hline CPI & PPT & CPI & PPT \\
\hline \hline Loss & -0.2 & 17.74 & 0 & 18.12 \\
$0.54 \operatorname{Var}\left(\pi_{t}^{h}\right)$ & 0.44 & 2.22 & 0 & 1.68 \\
$0.03 \operatorname{Var}\left(\widehat{Y}_{t}\right)$ & 0.09 & 0.86 & 0 & 0.74 \\
$0.86 \operatorname{Var}\left(\widehat{R E R_{t}}\right)$ & -0.73 & 14.66 & 0 & 15.7 \\
\hline \hline
\end{tabular}


Values are in the percent deviation of corresponding entry from the benchmark acyclical fiscal policy combined with CPI targeting monetary rule under a flexible exchange rate regime.

According to the parametrization of De Paoli (2009), the welfare loss weights for variances of domestic price inflation, output, and real exchange rate are 0.54, 0.03, and 0.86 respectively. These weights are used to calculate entries in Table 2 in order to compare with Table 1, where equal unit weights are assumed. The results show that the best policy combination becomes a managed exchange rate regime under a countercyclical fiscal stance and CPI targeting monetary rule, since a weight on the exchange rate variance is relatively high. Across all types of fiscal policy and monetary rules, a managed exchange rate regime is preferred to a flexible exchange rate regime, because a stable exchange rate may concern authorities more, who therefore put higher weight on it in their objective function. Yet inflation and output are still better stabilized under a flexible exchange rate regime, supporting the previous finding that a managed exchange rate regime causes volatility in other variables by intervening in the foreign exchange market.

\section{Conclusion}

This paper develops the DSGE model for an emerging oil economy, to study the lossminimizing monetary policy rule jointly with a pro/counter/acyclical fiscal stance. The model allows the UIP to be derived from the first-order conditions of the forward-looking household, so that the foreign exchange reserves appear in the UIP equation, supporting the mechanism described by Benes et al. (2015). The study reveals that the best policy combination is a countercyclical fiscal stance and CPI inflation monetary targeting under a flexible exchange rate regime. This allows the fiscal policy to countercyclically offset a volatile terms of trade shock, to which developing countries are often exposed, the monetary policy to stabilize the CPI inflation, which includes import prices that are important for private consumption rather than oil price in a PPT anchor. It also allows the exchange rate to flexibly adjust without the central bank's interventions, which, otherwise, under a managed exchange rate regime, cause high volatility in other variables, except 
the exchange rate. The impulse-response functions to the negative world oil price shock, as a sudden worsening of the terms of trade, show that monetary policy rule's response to inflation matters for the interest rate dynamics, rather than the target itself as Frankel and Catao (2011) suggest. In fact, the PPT rule is worse than the CPI, causing larger variations particularly in output and exchange rate. To conclude, the volatile terms of trade can be stabilized by an appropriate domestic policy combination or, in other words, fiscal and monetary coordination to smooth the effects of external shocks on aggregate output, real exchange rate, and domestic price inflation in a small open economy.

\section{References}

[1] Algozhina, A. (2012). Monetary and fiscal policy interactions in an emerging open economy: a non-Ricardian DSGE approach. CERGE-EI Working Paper, 476, 1-28.

[2] Allegret, J. P., \& Benkhodja, M. T. (2015). External shocks and monetary policy in an oil exporting economy (Algeria). Journal of Policy Modeling, 37, 652-667.

[3] Benes, J., Berg, A., Portillo, R., \& Vavra, D. (2015). Modeling sterilized interventions and balance sheet effects of monetary policy in a New Keynesian framework. Open Economies Review, 26, 81-108.

[4] Berg, A., Portillo, R., Yang, S., \& Zanna, L-F. (2013). Public investment in resourceabundant developing countries. IMF Economic Review, 61(1), 92-129.

[5] Bodenstein, M., Erceg, C. J., \& Guerrieri, L. (2011). Oil shocks and external adjustment. Journal of International Economics, 83(2), 168-184.

[6] Bornhorst, F., Dobrescu, G., Fedelino, A., Gottschalk, J., \& Nakata, T. (2011). When and how to adjust beyond the business cycle? A guide to structural fiscal balances. IMF Tecnhical Notes and Manuals, TNM/11/02, 1-36.

[7] Calvo, G. (1983). Staggered prices in a utility maximizing framework. Journal of Monetary Economics, 12(3), 383-398.

[8] Cochrane, J. H. (2011). Understanding policy in the great recession: some unpleasant fiscal arithmetic. European Economic Review, 55(1), 2-30.

[9] Coenen, G., Lombardo, G., Smets, F., \& Straub, R. (2007). International transmission and monetary policy cooperation. In J. Gali and M. Gertler (Eds.), International dimensions of monetary policy (pp. 157-195). Chicago, IL: The University of Chicago Press.

[10] Dagher, J., Gottschalk, J., \& Portillo, R. (2010). Oil windfalls in Ghana: a DSGE approach. IMF Working Paper, WP/10/116, 1-36. 
[11] Davig, T., \& Leeper, E. M. (2011). Monetary-fiscal policy interactions and fiscal stimulus. European Economic Review, 55(2), 211-227.

[12] De Paoli, B. (2009). Monetary policy and welfare in a small open economy. Journal of International Economics, 7r(1), 11-22.

[13] Dib, A. (2008). Welfare effects of commodity price and exchange rate volatilities in a multi-sector small open economy model. Bank of Canada Working Paper, 2008-8, $1-53$.

[14] Edge, R. M. (2003). A utility-based welfare criterion in a model with endogenous capital accumulation. Finance and Economics Discussion Series of the Federal Reserve Board, 2003-66, 1-39.

[15] Faia, E., \& Iliopulos, E. (2011). Financial openness, financial frictions and optimal monetary policy. Journal of Economic Dynamics and Control, 35(11), 1976-1996.

[16] Frankel, J. A., \& Catao, L. A. V. (2011). A comparison of product price targeting and other monetary anchor options for commodity exporters in Latin America. Economia, 12(1), 1-70.

[17] Gali, J. (2015). Monetary policy, inflation, and the business cycle: an introduction to the New Keynesian framework and its applications. Princeton, NJ: Princeton University Press, 1-279.

[18] Gali, J., Lopez-Salido, J. D., \& Valles, J. (2007). Understanding the effects of government spending on consumption. Journal of the European Economic Association, $5(1), 227-270$.

[19] Gartner, M. (1987). Intervention policy under floating exchange rates: an analysis of the Swiss case. Economica, 54(216), 439-453.

[20] Jakab, Z. M., \& Vilagi, B. (2008). An estimated DSGE model of the Hungarian economy. Magyar Nemzeti Bank Working Paper, 2008/9, 3-81.

[21] Leeper, E. M. (1991). Equilibria under "active" and "passive" monetary and fiscal policies. Journal of Monetary Economics, 27(1), 129-147.

[22] Leeper, E. M. (2013). Fiscal limits and monetary policy. NBER Working Paper, 1887r, 1-22.

[23] Mankiw, N. G. (2000). The savers-spenders theory of fiscal policy. American Economic Review, 90(2), 120-125.

[24] Nakov, A., \& Pescatori, A. (2010). Oil and the Great Moderation. Economic Journal, 120(543), 131-156.

[25] Ostry, J. D., Ghosh, A. R., \& Chamon, M. (2012). Two targets, two instruments: monetary and exchange rate policies in emerging market economies. IMF Staff Discussion Note, SDN/12/01, 1-24.

[26] Pieschacon, A. (2012). The value of fiscal discipline for oil-exporting countries. Journal of Monetary Economics, 59(3), 250-268. 
[27] Reinhart, C. M., \& Reinhart, V. R. (2008). Capital inflows and reserve accumulation: the recent evidence. NBER Working Paper, 13842, 1-24.

[28] Rioja, F. K. (2003). Filling potholes: macroeconomic effects of maintenance versus new investments in public infrastructure. Journal of Public Economics, 87, 22812304 .

[29] Sab, R., \& Smith, S. C. (2002). Human capital convergence: a joint estimation approach. IMF Staff Papers, $49(2), 200-211$.

[30] Sarno, L., \& Taylor, M. P. (2001). Official intervention in the foreign exchange market: is it effective and, if so, how does it work? Journal of Economic Literature, $39(3), 839-868$.

[31] Schmitt-Grohe, S., \& Uribe, M. (2003). Closing small open economy models. Journal of International Economics, 61(1), 163-185.

[32] Traum, N., \& Yang, S. (2011). When does government debt crowd out investment? Society for Economic Dynamics 2011 Meeting Papers, 479, 1-42.

[33] Walsh, C. E. (2010). Monetary Theory and Policy. Cambridge, MA: MIT Press, $1-613$.

[34] Woodford, M. (2003). Interest and prices: foundations of a theory of monetary policy. Princeton, NJ: Princeton University Press, 1-785. 


\section{A Calibration}

\begin{tabular}{|c|c|}
\hline Parameter & Definition \\
\hline$\beta=0.978$ & discount factor \\
\hline$\gamma=0.68$ & home-bias in consumption and investment \\
\hline$\gamma_{2}=0.9$ & home-bias in government purchases \\
\hline$\Omega=0.54$ & upper bound of leverage ratio \\
\hline$\mu=0.5$ & fraction of rule-of-thumb households \\
\hline$\alpha=0.3$ & non-oil output elasticity to private capital \\
\hline$\psi=0.16$ & non-oil output elasticity to public capital \\
\hline$\alpha^{o}=0.7$ & oil output elasticity to private capital \\
\hline$\phi=1.45$ & wage elasticity to hours worked \\
\hline$\sigma=2$ & inverse of intertemporal elasticity of substitution for consumption \\
\hline$\delta=0.025$ & depreciation rate of private capital (oil and non-oil) \\
\hline$\delta^{g}=0.02$ & depreciation rate of public capital \\
\hline$\theta=0.9$ & index of price stickiness \\
\hline$\varepsilon=9$ & elasticity of substitution b/w differentiated intermediate goods \\
\hline$\kappa=20$ & investment adjustment costs parameter \\
\hline$\phi_{y}=0.1$ & output response in the Taylor rule \\
\hline$\phi_{\pi}=0.9$ & inflation response in the Taylor rule \\
\hline$\alpha_{1}=-0.47$ & exchange rate response in the interventions rule \\
\hline$\alpha_{2}=-0.6$ & exchange rate change response in the interventions rule \\
\hline$\tau^{o}=0.27$ & oil royalty rate \\
\hline$\iota^{\mathrm{div}}=0.05$ & dividend share of oil profit accrued to the government \\
\hline$\gamma_{G C}=\gamma_{G I}=0.3$ & response of public consumption/investment to fiscal debt \\
\hline$\vartheta_{G C}=\vartheta_{G I}=0.3$ & response of public consumption/investment to output \\
\hline$\gamma_{O R}^{G C}=0.2$ & response of public consumption to oil revenues \\
\hline$\gamma_{O R}^{G I}=0.1$ & response of public investment to oil revenues \\
\hline$\varphi_{b}=0.4$ & response of lump-sum taxes to fiscal debt \\
\hline$\varphi_{O R}=-0.3$ & response of lump-sum taxes to oil revenues \\
\hline$\varphi_{C}=1$ & response of lump-sum taxes to public consumption \\
\hline$\varphi_{I}=0.2$ & response of lump-sum taxes to public investment \\
\hline$\rho_{G C}=\rho_{G I}=0.33$ & persistence in public consumption/investment \\
\hline $1-\rho_{F D I}=0.8$ & FDI response to the world oil price \\
\hline$\rho_{s w f}=0.775$ & persistence in the SWF process \\
\hline$\rho=0.95$ & interest rate smoothing in the Taylor rule \\
\hline$\rho_{f x r}=0.57$ & persistence in the foreign exchange reserves of a central bank \\
\hline$\rho_{o}=0.74$ & persistence in the world oil price process \\
\hline$\sigma_{\epsilon_{t}^{o}}=\sigma_{\epsilon_{t}^{Y^{*}}}=0.14$ & standard deviation of the world oil price and foreign output shocks \\
\hline
\end{tabular}

\section{B Data description}

Data are outlined here, which are used in the regressions, calculated GDP ratios, and other calibrated parameters. Most data are manually retrieved from the non-English websites of respective institutions, which are indicated in parenthesis below. Some data were obtained based on a formal request to those institutions. The author can provide the collected database to those who are interested in research about Kazakhstan. 
Real GDP is the GDP at constant prices of 1994 in mln tenge according to the National Accounts over 1994Q1-2012Q2 (Agency of Statistics).

Private consumption is the consumption expenditures of households at constant prices of 1994 in mln tenge according to the National Accounts over 1994Q1-2012Q2 (Agency of Statistics).

Real public consumption is public consumption at constant prices of 1994 in mln tenge according to the National Accounts over 1994Q1-2012Q2 (Agency of Statistics).

Fixed capital formation is a gross fixed capital formation at constant prices of 1994 in mln tenge according to the National Accounts over 1994Q1-2012Q2 (Agency of Statistics).

Imports are the imports of goods and services at constant prices of 1994 in mln tenge according to the National Accounts over 1994Q1-2012Q2 (Agency of Statistics).

Net exports are the net exports at constant prices of 1994 in mln tenge according to the National Accounts over 1994Q1-2012Q2 (Agency of Statistics).

Oil output is the mining industry's output in mln tenge according to the composition of total industrial output statistics over 1998Q3-2012Q2 (Agency of Statistics).

CPI is a quarterly consumer price index over 1994Q1-2012Q2 (National Bank).

Real public debt is the CPI-deflated public debt, including debt guaranteed by the state, in mln tenge over 1999Q4-2012Q2 (Ministry of Finance).

Real oil revenues of government budget represent the CPI-deflated oil revenues of government budget till 2007 and transfers from the SWF to the government budget since 2007 in mln tenge over 2001Q2-2012Q2 (Ministry of Finance).

Real fiscal capital expenditures are the CPI-deflated capital expenditures of government budget in mln tenge over 2000Q1-2012Q2 (Ministry of Finance).

Real non-oil fiscal revenues are the CPI-deflated difference between total fiscal revenues and oil revenues of the government budget in mln tenge over 2000Q1-2012Q2 (Ministry of Finance).

T-bill rate is an effective annual return on medium-term Treasury bills in percent over 1998Q1-2012Q2 (Statistical Bulletin of the National Bank).

Producer price index is a quarterly producer price index over 1994Q1-2012Q2 (Agency of Statistics).

World oil price is a petroleum UK Brent price USD/barrel over 1993Q4-2012Q2 (International Financial Statistics of the IMF).

Real foreign exchange reserves are the CPI-deflated net foreign exchange reserves of the National Bank in mln tenge over 1994Q4-2012Q2 (National Bank).

Real exchange rate is a bilateral real exchange rate, tenge per 1 USD, over 1995Q12012Q2 (National Bank).

Real FDI is the US CPI-deflated foreign direct investments in mln USD according to the balance of payments statistics over 2002Q1-2012Q2 (National Bank). The US CPI index is retrieved from the International Financial Statistics of the IMF.

Foreign debt is an external debt of banks and other private entities in mln USD according to the balance of payments statistics over 1995Q1-2012Q2 (National Bank).

Wage is an average monthly wage of a hired employee in tenge over 1994Q1-2012Q4 (Agency of Statistics).

SWF inflows represent the oil revenues of government budget till 2007 and inflows into SWF since 2007 in mln tenge over 2001Q2-2012Q4 (Ministry of Finance).

SWF assets are the stock of SWF at the end of period in mln tenge over 2001Q22012Q4 (Ministry of Finance). 


\section{First-order conditions}

The first-order conditions of the forward-looking household's problem are listed in this appendix, where $\lambda_{t}, \lambda_{t}^{k}$, and $\lambda_{t} f x r_{t}^{*}$ are the Lagrange multipliers to the budget constraint (2), capital accumulation (3), and collateral constraint (4) respectively. Note that foreign exchange reserves $f x r_{t}^{*}$ are involved in the Lagrange multiplier to collateral constraint in order to obtain the UIP condition in line with Benes et al. (2015), who yet introduced it in an ad hoc fashion. The existence of collateral constraint in this model allows the UIP to include the foreign exchange reserves, since the foreign debt of the saver, denominated in foreign currency, needs to be backed by the foreign exchange reserves, denominated in foreign currency as well. Effectively, the Lagrange multiplier to collateral constraint $\lambda_{t} f x r_{t}^{*}$ would suggest this rate of marginal utility produced by a change in foreign debt.

$$
\begin{gathered}
U_{C_{t}^{S}}=\lambda_{t}=\frac{1}{\left[C_{t}^{S}-\frac{N_{t}^{\phi}}{\phi}\right]^{\sigma}} \\
\frac{1}{Q_{t}}=1-\frac{\kappa}{2}\left(\frac{I_{t}}{I_{t-1}}-1\right)^{2}-\kappa\left(\frac{I_{t}}{I_{t-1}}-1\right) \frac{I_{t}}{I_{t-1}}+\beta \kappa E_{t}\left\{\frac{Q_{t+1} \lambda_{t+1}}{Q_{t} \lambda_{t}}\left(\frac{I_{t+1}}{I_{t}}-1\right)\left(\frac{I_{t+1}}{I_{t}}\right)^{2}\right\}
\end{gathered}
$$

where $Q_{t}=\frac{\lambda_{t}^{k}}{\lambda_{t}}$

$$
\begin{gathered}
Q_{t}=E_{t}\left\{\beta \frac{\lambda_{t+1}}{\lambda_{t}}\left[R_{t+1}^{k n o}+Q_{t+1}(1-\delta)\right]+f x r_{t}^{*} \Omega \frac{Q_{t+1} \pi_{t+1}^{*}}{R E R_{t+1} / R E R_{t}}\right\} \\
\frac{1}{R_{t}}=\beta E_{t}\left\{\frac{U_{C_{t+1}^{S}}}{U_{C_{t}^{S}} \pi_{t+1}}\right\} \\
\frac{1}{R_{t}^{*}}=\beta E_{t}\left\{\frac{U_{C_{t+1}^{S}}}{U_{C_{t}^{S}}} \frac{R E R_{t+1}}{R E R_{t} \pi_{t+1}^{*}}\right\}+f x r_{t}^{*} \\
W_{t}=N_{t}^{\phi-1}
\end{gathered}
$$

By dividing (37) into (36), the following UIP condition is obtained:

$$
\frac{R_{t}}{R_{t}^{*}}=E_{t}\left\{\frac{R E R_{t+1}}{R E R_{t}} \frac{\pi_{t+1}}{\pi_{t+1}^{*}}\right\}+\frac{f x r_{t}^{*}}{\beta} E_{t}\left\{\frac{U_{C_{t}^{S}}}{U_{C_{t+1}^{S}}} \pi_{t+1}\right\}+\operatorname{cov}_{t}
$$

where $\operatorname{cov}_{t}$ captures covariance terms.

The first-order conditions of rule-of-thumb household with respect to consumption $C_{t}^{N}$ and hours worked $N_{t}$ are identical to the saver's solutions. Thus, a non-saver faces the same labor supply condition (38).

\section{Steady state}

The model's steady state assumes zero inflation, thus it is at flexible prices. Variables at steady state are denoted by bars and presented in this appendix. 
The first-order condition of a forward-looking household with respect to the government bonds (36) gives that $\bar{R}=\frac{1}{\beta}$, while with respect to the foreign debt (37) suggests $\overline{f x r^{*}}=\beta^{*}-\beta$ at steady state. Similarly, $\bar{R}^{*}=\frac{1}{\beta^{*}}$.

The first-order condition of an oil producer with respect to capital equalizes the marginal factor product to its price:

$$
\alpha^{o}\left(1-\tau^{o}\right)\left(\overline{K^{o}}\right)^{\alpha^{o}-1}=\overline{R^{o k}}=\frac{1}{\beta}-(1-\delta),
$$

from which the steady state of oil capital can be found.

$$
\overline{K^{o}}=\left[\frac{1 / \beta-(1-\delta)}{\alpha^{o}\left(1-\tau^{o}\right)}\right]^{\frac{1}{\alpha^{o}-1}}
$$

Since oil capital is known, the oil output, FDI, and SWF are obtained from their respective equations (12), (14), and $(16,20,21)$ :

$$
\overline{Y^{o}}=\left(\overline{K^{o}}\right)^{\alpha^{o}}, \quad \overline{F D I^{*}}=\delta \overline{K^{o}}, \quad \overline{S W F}=\frac{\left[\tau^{o}+\iota^{\operatorname{div}}\left(1-\tau^{o}\right)\right] \overline{Y^{o}}}{1-\rho_{s w f}}
$$

The law of one price holds so that the real exchange rate and relative prices at their steady state equal to 1 .

The oil revenues of the government budget are as follows:

$$
\overline{O R}=\left(\overline{R^{*}}-\rho_{s w f}\right) \overline{S W F R E R}
$$

The public capital accumulation equation (19) gives public investment at steady state:

$$
\overline{G_{I}}=\delta^{g} \overline{K_{G}}
$$

Fiscal debt is represented in terms of public capital, using the public investment equation (22) and the expression above:

$$
\bar{b}=\left(\frac{\bar{Y}_{o}^{\vartheta_{G I}} \overline{O R}^{\gamma_{O F}^{G I}}}{\delta^{g} \overline{K_{G}}}\right)^{\frac{1}{\gamma_{G I}}}
$$

Public consumption is as follows, based on its rule (23), in which fiscal debt can be plugged into from the previous equation:

$$
\overline{G_{C}}=\frac{\bar{Y}_{o}^{\vartheta_{G C}} \overline{O R}^{\gamma_{O F}^{G C}}}{\bar{b}^{\gamma_{G C}}}
$$

The lump-sum taxes equation (24) suggests taxes at steady state:

$$
\bar{T}=\frac{\bar{b}^{\varphi_{b}}{\overline{G_{I}}}^{\varphi_{I}}{\overline{G_{C}}}^{\varphi_{C}}}{\overline{O R}^{\varphi_{O R}}}
$$

The government budget constraint (17) can be used to obtain public capital by substituting the fiscal debt, oil revenues, public consumption, and public investment with their 
respective previous expressions:

$$
\bar{T}+\overline{O R}=\overline{G_{I}}+\overline{G_{C}}+(1-\mu)(\bar{R}-1) \bar{b}
$$

The first-order condition with respect to non-oil capital (35) yields the following rental cost of capital:

$$
\overline{R^{k n o}}=\frac{1}{\beta}-(1-\delta)-\overline{\frac{f x r^{*}}{\beta}}
$$

The price setting problem of a non-oil firm suggests that the real marginal costs (9) equate with the inverse of price frictionless mark-up $\frac{\varepsilon}{\varepsilon-1}$ at steady state; thus, wages are:

$$
\bar{W}=(1-\alpha)\left[\frac{\bar{K}_{G}^{\psi} \alpha^{\alpha}(\varepsilon-1)}{\left(\overline{R^{k n o}}\right)^{\alpha} \varepsilon}\right]^{\frac{1}{1-\alpha}}
$$

The labor supply condition (38) gives $\bar{N}=\bar{W}^{\frac{1}{\phi-1}}$.

As aggregate output is a sum of non-oil and oil output $\bar{Y}=\overline{Y_{n o}}+\overline{R E R Y_{o}}=\bar{N}^{1-\alpha}{\overline{K_{G}}}^{\psi}{\overline{K_{n o}}}^{\alpha}+$ $\overline{R E R Y_{o}}$. The non-oil capital is obtained in terms of aggregate output:

$$
\overline{K_{n o}}=\left(\frac{\bar{Y}-\overline{R E R Y_{o}}}{\bar{N}^{1-\alpha}{\overline{K_{G}}}^{\psi}}\right)^{\frac{1}{\alpha}}
$$

The law of motion for capital (3) relates private investment with the non-oil capital: $\bar{I}=\delta \overline{K_{n o}}$.

The collateral constraint (4) allows the finding of the foreign debt:

$$
\overline{b^{*}}=\frac{\Omega \overline{K_{n o}}}{\bar{R}^{*}}
$$

The balance of payments equation provides net exports:

$\overline{N X}=(1-\mu)\left(\bar{R}^{*}-1\right) \overline{b^{*}}-\overline{R E R F D I^{*}}-\left(\overline{R^{*}}-\rho_{s w f}\right) \overline{S W F R E R}+\left(1-\iota^{\operatorname{div}}\right) \overline{R E R}\left(1-\tau^{o}\right) \overline{Y^{o}}$

The taxes of rule-of-thumb households are equal to:

$$
\overline{T^{N}}=\frac{\bar{T}-(1-\mu) \overline{T^{S}}}{\mu}
$$

given that $T_{t}=\mu T_{t}^{N}+(1-\mu) T_{t}^{S}$, while the taxes of savers can be derived from the budget constraint $(2)^{11}$, assuming that both types of household have equal consumption at steady state:

$$
\overline{T^{S}}=\mu\left[\left(\overline{R^{k n o}}-\delta\right) \overline{K^{n o}}+\bar{b}(\bar{R}-1)+\overline{b^{*}}\left(1-\overline{R^{*}}\right)+\left(1-\frac{\varepsilon-1}{\varepsilon}\right) \overline{Y^{n o}}\right]+\bar{T}
$$

\footnotetext{
${ }^{11}$ According to Benes et al. (2015), the budget constraint of households contains the cash-flow transfers from a central bank, which at steady state in this model would be equal to $-\frac{\left(\beta^{*}-\beta\right)^{2}}{\beta^{*} \beta}$, therefore they represent a small number that wouldn't significantly affect the saver's taxes.
} 
The budget constraint of a rule-of-thumb household (5) provides its consumption $\overline{C^{N}}=$ $\overline{W N}-\overline{T^{N}}$, which is assumed to be equal to the saver's consumption, thus to aggregate consumption as well due to the summation of both households' consumption: $\bar{C}=\mu \overline{C^{N}}+$ $(1-\mu) \overline{C^{S}}$.

The real GDP condition (29) can be utilized to derive the aggregate output by plugging into variables, expressed in terms of output according to their steady state equations above:

$$
\bar{Y}=\bar{C}+(1-\mu) \bar{I}+\overline{G_{C}}+\overline{G_{I}}+\overline{N X}
$$

\section{E The Phillips curve}

The Phillips curve for CPI inflation in a small open economy has been derived according to Gali (2015).

The log-linearized optimal price setting condition (11) delivers a standard equation for domestic inflation $\pi_{t}^{h}$ :

$$
\pi_{t}^{h}=\beta E_{t} \pi_{t+1}^{h}+\lambda \frac{1-\alpha}{1-\alpha+\alpha \varepsilon} \widehat{m c_{t}}
$$

where $\widehat{m c_{t}}$ is the log deviation of the economy's average real marginal costs from their steady state and $\lambda=\frac{(1-\beta \theta)(1-\theta)}{\theta}$.

The CPI inflation includes the domestic inflation $\pi_{t}^{h}$ and the terms of trade, which can be alternatively represented by the real exchange rate $R E R_{t}$ :

$$
\pi_{t}=\pi_{t}^{h}+\frac{1-\gamma}{\gamma} \triangle \widehat{R E R_{t}}
$$

The Phillips curve then is as follows:

$$
\pi_{t}=\beta E_{t} \pi_{t+1}+\lambda \frac{1-\alpha}{1-\alpha+\alpha \varepsilon} \widehat{m c}_{t}+\frac{1-\gamma}{\gamma} \Delta \widehat{R E R}_{t}-\beta \frac{1-\gamma}{\gamma} E_{t} \Delta \widehat{R E R}_{t+1},
$$

where $\widehat{m c}_{t}=\widehat{W}_{t}-\left(\widehat{Y_{t}^{n o}}-\widehat{N_{t}}\right)+\frac{1-\gamma}{\gamma} \widehat{R E R_{t}}$. Wages can be substituted with the log-linearized labor supply condition (38), so that the Phillips curve used in the model is this:

$$
\begin{aligned}
\pi_{t}= & \beta E_{t} \pi_{t+1}+\frac{1-\gamma}{\gamma}\left(\lambda \frac{1-\alpha}{1-\alpha+\alpha \varepsilon}+\beta+1\right) \widehat{R E R}_{t}-\frac{1-\gamma}{\gamma} \widehat{R E R}_{t-1} \\
& -\beta \frac{1-\gamma}{\gamma} E_{t} \widehat{R E R}_{t+1}+\lambda \frac{1-\alpha}{1-\alpha+\alpha \varepsilon}\left(\phi \widehat{N}_{t}-\widehat{Y Y}_{t}^{n o}\right)
\end{aligned}
$$

\section{F Log-linearized equations}

The aggregate consumption equation is derived according to Gali, Lopez-Salido, and Valles (2007) by combining the Euler equation (36), budget constraint of the rule-ofthumb households (5), and the relationship $C_{t}=\mu C_{t}^{N}+(1-\mu) C_{t}^{S}$ :

$$
\widehat{C}_{t}=E_{t} \widehat{C}_{t+1}+\Theta_{n}\left(\widehat{N}_{t}-E_{t} \widehat{N}_{t+1}\right)-\Theta_{i}\left(\widehat{R}_{t}-E_{t} \pi_{t+1}\right)+\mu \overline{T C}^{-1}\left(\widehat{T}_{t+1}-\widehat{T}_{t}\right),
$$


where $\Theta_{n}=\left[\mu \bar{N}^{\phi} \phi+(1-\mu) \bar{N}^{\phi}\right] \bar{C}^{-1}$ and $\Theta_{i}=(\sigma \bar{C})^{-1}(1-\mu)\left(\bar{C}-\phi^{-1} \bar{N}^{\phi}\right)$.

The combination of the first-order condition with respect to non-oil capital (35) and investment (34) given that $\widehat{R_{t}^{k n o}}=\phi \widehat{N_{t}}-\widehat{K_{t-1}^{n o}}$ delivers the following:

$$
\begin{aligned}
\kappa(1+\beta) \widehat{I}_{t}= & \left(\beta(1-\delta)+\Omega \overline{f x r}^{*}\right)\left[\kappa(1+\beta) E_{t} \widehat{I_{t+1}}-\kappa \beta E_{t} \widehat{I_{t+2}}-\kappa \widehat{I}_{t}\right]+\kappa \beta E_{t} \widehat{I_{t+1}}(43) \\
& +\left(1-\beta(1-\delta)-\Omega \overline{f x r}^{*}\right) E_{t}\left[\phi \widehat{N_{t+1}}-\widehat{K_{t}^{n o}}\right]-\frac{\bar{C}-\bar{N}^{\phi} / \phi}{\sigma \bar{C}}\left(\widehat{R}_{t}-E_{t} \pi_{t+1}\right) \\
& +\kappa \widehat{I_{t-1}}+\Omega \overline{f x r}^{*}\left(E_{t} \pi_{t+1}^{*}+\widehat{R E R}_{t}-E_{t} \widehat{R E R}_{t+1}+\widehat{f x r_{t}^{*}}\right)
\end{aligned}
$$

The log-linearization of the balance of payments equation results in this:

$$
\begin{aligned}
\widehat{N X}_{t}= & {\left[\frac{\overline{R^{*}} b_{y}^{*}(1-\mu)}{n x_{y}}-\frac{\left(\bar{R}^{*}-\rho_{s w f}\right) s w f_{y}}{n x_{y}}-\frac{f d i_{y}}{n x_{y}}+\frac{\left(1-\iota^{\mathrm{div}}\right)\left(1-\tau^{o}\right) s_{o}}{n x_{y}}\right] \widehat{R E R}_{t} } \\
& -\frac{b_{y}^{*}(1-\mu) \widehat{b}_{t}^{*}}{n x_{y}}+\frac{\overline{R^{*}} b_{y}^{*}(1-\mu)_{\widehat{b}_{t-1}^{*}}+\frac{\bar{R}^{*} s w f_{y}-(1-\mu) \overline{R^{*}} b_{y}^{*}}{n x_{y}} \pi_{t}^{*}-\frac{f d i_{y}}{n x_{y}} \widehat{F D I_{t}^{*}}}{} \\
& -\frac{\overline{R^{*}} b_{y}^{*}(1-\mu)}{n x_{y}} \widehat{R E R} \widehat{R}_{t-1}+\frac{\left(1-\iota^{\mathrm{div}}\right)\left(1-\tau^{o}\right) s_{o}}{n x_{y}} \widehat{Y}_{t}^{o}-\frac{\left(\bar{R}^{*}-\rho_{s w f}\right) s w f_{y}}{n x_{y}} \widehat{S W F}_{t-1} \\
& +\frac{(1-\mu) b_{y}^{*}-s w f_{y}}{n x_{y}} \widehat{R}_{t-1}^{*}+\frac{\left(1-\iota^{\mathrm{div}}\right)\left(1-\tau^{o}\right) s_{o}}{n x_{y}} \widehat{P}_{t}^{o *}
\end{aligned}
$$

The collateral constraint (4) combined with the first-order condition with respect to investment (34) yields:

$$
\widehat{b}_{t}^{*}=E_{t} \pi_{t+1}^{*}-\widehat{R}_{t}^{*}+\widehat{K_{t}^{n o}}+\widehat{R E R}+E_{t} \widehat{R E R} \widehat{R}_{t+1}+\kappa(1+\beta) E_{t} \widehat{I_{t+1}}-\kappa \beta E_{t} \widehat{I_{t+2}}-\kappa \widehat{I}_{t}
$$

The law of motion for non-oil capital (3) is as follows:

$$
\widehat{K_{t}^{n o}}=(1-\delta) \widehat{K_{t-1}^{n o}}+\delta \widehat{I_{t}}
$$

Similarly, the public capital accumulation (19) in its log-linearized form is below:

$$
\widehat{K_{t}^{G}}=\left(1-\delta^{g}\right) \widehat{K_{t-1}^{G}}+\delta^{g} \widehat{G_{t}^{I}}
$$

The oil capital is accumulated by FDI according to its equation (13):

$$
\widehat{K_{t}^{o}}=(1-\delta) \widehat{K_{t-1}^{o}}+\delta \widehat{F D I_{t}^{*}}
$$

The combination of oil tax revenues equation (20), SWF accumulation (21), and the profits of oil producer (16) corresponds to:

$$
\widehat{S W F}_{t}=\rho_{s w f} \widehat{S W F}_{t-1}+\frac{\left[\tau^{o}+\iota^{\operatorname{div}}\left(1-\tau^{o}\right)\right] s_{o}}{s w f_{y}}\left(\widehat{Y}_{t}^{o}+\widehat{P}_{t}^{o *}\right)
$$


The UIP condition (39) after some tedious algebra is as follows:

$$
\widehat{R}_{t}=E_{t} \pi_{t+1}+\frac{\beta^{*}}{\beta} \widehat{R}_{t}^{*}-E_{t} \pi_{t+1}^{*}+E_{t} \widehat{R E R}_{t+1}-\widehat{R E R}_{t}+\left(\frac{\beta^{*}}{\beta}-1\right) \widehat{f x r_{t}^{*}}
$$

The non-oil and oil production functions (8 and 12) give respectively:

$$
\begin{gathered}
\widehat{Y_{t}^{n o}}=\alpha \widehat{K_{t-1}^{n o}}+(1-\alpha) \widehat{N}_{t}+\psi \widehat{K}_{G, t-1} \\
\widehat{Y_{t}^{o}}=\alpha^{o} \widehat{K_{t-1}^{o}}
\end{gathered}
$$

The aggregate output is as follows:

$$
\widehat{Y}_{t}=\left(1-s_{o}\right) \widehat{Y_{t}^{n o}}+\left(1-s_{o}\right) \widehat{p_{t}^{h}}+s_{o}\left(\widehat{Y}_{t}^{o}+\widehat{R E R}+\widehat{P_{t}^{o *}}\right)
$$

The government budget constraint (17) in terms of fiscal debt results in:

$$
\begin{aligned}
\widehat{b}_{t}= & \bar{R}\left(\widehat{b}_{t-1}+\widehat{R}_{t-1}-\pi_{t}\right)+\frac{g_{y}^{I}}{(1-\mu) b_{y}} \widehat{G_{t}^{I}}+\frac{g_{y}^{C}}{(1-\mu) b_{y}} \widehat{G_{t}^{C}}+\frac{g_{y}^{C}+g_{y}^{I}}{(1-\mu) b_{y}} \widehat{p_{t}^{g}} \\
& -\frac{\bar{T}}{\bar{b}(1-\mu)} \widehat{T}_{t}-\frac{\left(\bar{R}^{*}-\rho_{s w f}\right) s w f_{y}}{b_{y}(1-\mu)} \widehat{O R}_{t}
\end{aligned}
$$

where oil revenues are as follows $\widehat{O R}_{t}=\widehat{R E R_{t}}+\widehat{S W F}_{t-1}+\frac{1}{\overline{\bar{R}}^{*}-\rho_{s w f}} \widehat{R}_{t-1}^{*}-\frac{\bar{R}^{*}}{\bar{R}^{*}-\rho_{s w f}} \pi_{t}^{*}$.

The log-linearized relative price of government purchases to composite consumption (18), assuming $\eta \rightarrow 1$, is this:

$$
\widehat{p_{t}^{g}}=\gamma_{2} \widehat{p_{t}^{h}}+\left(1-\gamma_{2}\right) \widehat{R E R_{t}}
$$

The domestic goods market clearing condition (28) can be rewritten as:

$$
\widehat{Y_{t}^{n o}}+\widehat{p_{t}^{h}}=\frac{\gamma c_{y}}{\left(1-s_{o}\right)} \widehat{C}_{t}+\frac{(1-\mu)\left(1-i_{y}\right) \gamma}{\left(1-s_{o}\right)} \widehat{I}_{t}+\frac{\gamma_{2} g_{y}^{C}}{\left(1-s_{o}\right)} \widehat{G_{t}^{C}}+\frac{\gamma_{2} g_{y}^{I}}{\left(1-s_{o}\right)} \widehat{G_{t}^{I}}+\frac{\gamma_{2}\left(g_{y}^{C}+g_{y}^{I}\right)}{\left(1-s_{o}\right)} \widehat{p_{t}^{g}},
$$

where $\left(1-i_{y}\right)=1-c_{y}-g_{y}^{C}-g_{y}^{I}-n x_{y}$.

The real GDP (29) is represented in terms of investment:

$$
\widehat{I}_{t}=\frac{1}{\left(1-i_{y}\right)(1-\mu)}\left[\widehat{Y}_{t}-c_{y} \widehat{C}_{t}-g_{y}^{C} \widehat{G_{t}^{C}}-g_{y}^{I} \widehat{G}_{t}^{I}-\left(g_{y}^{C}+g_{y}^{I}\right) \widehat{p}_{t}^{g}-n x_{y} \widehat{N X}_{t}\right]
$$




\begin{abstract}
Abstrakt
Frankel a Catao tvrdí, že politika cílení cenového indexu spotřebních cen je výrazně proti-cyklická. Z tohoto důvodu doporučují rozvíjejícím se ekonomikám používání politiky cílení cenového indexu výstupu namísto cílení cenového indexu spotřebních cen. Tato studie zkoumá model všeobecné stochastické rovnováhy, jež obsahuje jak měnovou tak fiskální politiku, a který je zamýšlen pro rozvíjející se ekonomiku produkující ropu. Cúlem této studie je odhadnout správná pravidla měnové politiky za předpokladu, že fiskální politika je bud' pro-cyklická anebo naopak proti-cyklická. Pro měnovou politiku flexibilního směnného kurzu je charakteristická absence měnových intervencí. Naproti tomu měnová politika řízeného měnového kurzu je charakterizována právě těmito intervencemi. Fiskální politika může být bud' pro-cyklická, anebo proti-cyklická a to podle toho, jaký je vztah mezi veřejnou spotřebou a investicemi na produkci ropy. Optimální hospodářskou politikou se ukazuje být proti-cyklická fiskální politika v kombinaci s měnovou politikou cílování cenového indexu spotřebitelských cen při současném udržování flexibilního směnného kurzu. Tato politika stabilizuje cenovou inflaci, celkový výstup a reálný směnný kurz malé otevřené ekonomiky.
\end{abstract}




\section{Working Paper Series}

ISSN 1211-3298

Registration No. (Ministry of Culture): E 19443

Individual researchers, as well as the on-line and printed versions of the CERGE-EI Working Papers (including their dissemination) were supported from institutional support RVO 67985998 from Economics Institute of the CAS, v. v. i.

Specific research support and/or other grants the researchers/publications benefited from are acknowledged at the beginning of the Paper.

(c) Aliya Algozhina, 2016

All rights reserved. No part of this publication may be reproduced, stored in a retrieval system or transmitted in any form or by any means, electronic, mechanical or photocopying, recording, or otherwise without the prior permission of the publisher.

Published by

Charles University, Center for Economic Research and Graduate Education (CERGE)

and

Economics Institute of the CAS, v. v. i. (EI)

CERGE-El, Politických vězňů 7, 11121 Prague 1, tel.: +420 224005 153, Czech Republic.

Printed by CERGE-EI, Prague

Subscription: CERGE-EI homepage: http://www.cerge-ei.cz

Phone: + 420224005153

Email: office@cerge-ei.cz

Web: http://www.cerge-ei.cz

Editor: Jan Zápal

The paper is available online at http://www.cerge-ei.cz/publications/working_papers/.

ISBN 978-80-7343-379-6 (Univerzita Karlova, Centrum pro ekonomický výzkum a doktorské studium)

ISBN 978-80-7344-395-5 (Národohospodářský ústav AV ČR, v. v. i.) 
CERGE-EI

P.O.BOX 882

Politických vězňů 7

11121 Praha 1

Czech Republic http://www.cerge-ei.cz 